\title{
Patterns of prominence, phrasing and tonal events in Spanish news reading: An illustrative case study
}

\author{
Lourdes Aguilar and Yurena M. Gutiérrez-González \\ Universitat Autònoma de Barcelona (Spain) \\ lourdes.aguilar@uab.cat ORCID: https://orcid.org/0000-0003-4619-9046 \\ yurenamaria.gutierrez@uab.cat ORCID: https://orcid.org/0000-0002-8459-551X
}

Enviado: 08/11/2017. Aceptado: 30/11/2017. Publicado online: 28/08/2018

Citation / Cómo citar este artículo: Lourdes Aguilar and Yurena M. Gutiérrez-González. (2018). Patterns of prominence, phrasing and tonal events in Spanish news reading: An illustrative case study, 5(1), e048. https://doi.org/10.3989/ loquens. 2018.048

RESUMEN: Patrones en la estructural acentual, organización prosódica y entonación en la lectura de noticias en español: un estudio de casos. - El presente estudio examina los patrones más comunes en la estructura acentual, la organización prosódica y la entonación en un corpus de noticias leído por profesionales de la radio con el fín de describir las estrategias prosódicas que pueden considerarse como rasgos diferenciadores de un estilo propio.

La anotación perceptiva de los fenómenos prosódicos permite, en primer lugar, establecer las principales modificaciones acentuales, que tienen que ver con la acentuación de sílabas átonas, el cambio de posición de acento para marcar el inicio de palabra y el mantenimiento de acentos en sílabas contiguas. En segundo lugar, la singularidad en la organización prosódica se relaciona con la aparición de pausas no justificadas por criterios sintácticos ni prosódicos, pero que enmarcan las unidades que ofrecen nueva información, y el realce del inicio de los grupos prosódicos con el objetivo de atraer la atención del oyente. Finalmente, los eventos tonales más relevantes que identifican la locución de los locutores profesionales son: el uso recurrente de acentos tonales ascendentes cuyo máximo de $f_{0}$ coincide con la sílaba acentuada, una gran variedad de tonos de trayectoria no descendente en el límite de frases intermedias, y el uso de tonos circunflejos al final de los enunciados de entonación.

Las estrategias descritas contribuyen a conseguir un estilo enfático y son representativas de un estilo de habla con esquemas prosódicos propios.

Palabras clave: fonología de la entonación; prominencia; organización prosódica; tonos; lectura de noticias.

\begin{abstract}
The present study examines the patterns in stress, phrasing and intonation found in a Spanish corpus of news read by broadcasters to describe the prosodic strategies that can be considered as genre-distinguishing features.

Results indicate that, firstly, the main stress modifications concern the upgrading of unstressed syllables to accented ones, the stress shift to mark word-initial boundaries and the maintenance of adjacent stresses. Secondly, the special features related to phrasing are unexpected pauses, which enhance the prosodic units that offer new information, and the prosodic marking of initial edges of groups with the aim of capturing the listener's attention. Finally, the most relevant tonal events that identify the typical chanting of broadcasters are a recurrent use of rises whose $f_{0}$ peak coincides with the stressed syllable, a variety of non-falling pitch movements signalling intermediate phrasing, and the use of rising-falling pitch movements to signal ends.

All the described prosodic and tonal strategies contribute to obtaining an emphatic style in news reading and are representative of a prosodically marked genre.
\end{abstract}

Keywords: intonational phonology; prominence; phrasing; tonal events; news reading. 


\section{INTRODUCTION}

The development of prosodic databases and studies based on large corpora rather than on well-controlled experiments are a useful way of taking the research in the prosodic field a step further (Botinis, Granstrom, \& Mobius, 2001; Hirschberg, 2002). Questions such as the definition of prominence and the corresponding production and perception cues, together with the influence that the prominent segments exert on the prosodic organisation are under discussion (Wagner et al., 2015) and call for the need of collecting empirical data that can shed light on the variability of prosody. Besides experimental procedures that can isolate variables and measure the weight of each of them on the object of study, great compilations of speech allow the exploration of intonational and prosodic patterns in language use.

Nevertheless, the corpus approach in prosodic studies is complex, since the transcription of prosodic features needs reference systems that are generally in a process of consolidation and involves a long-term phase of training and manual work by the annotators (which is the case for the ToBI model; Beckman, Hirschberg, \& Shattuck-Hufnagel, 2005). There exist some corpora for Spanish that include prosodic annotations-the Val.Es.Co corpus for the study of colloquial Spanish (Albelda Marco, 2005), or the C-ORAL-ROM corpus (Cresti \& Moneglia, 2005)—, and other corpora specially designed for the description of prosody - among others, the AMPER (Fernández Planas, 2005) and the MULTEXT (Campione \& Veronis, 1998) multilingual corpora, which include Spanish, or the Interactive Atlas of Spanish Intonation (Prieto \& Roseano, 2009-2013). Besides these projects, the Glissando corpus has been conceived as a corpus for multidisciplinary prosodic studies in Spanish (and in Catalan) with the main aim of offering to the scientific community a corpus recorded under optimal acoustic conditions, orthographically transcribed, phonetically aligned and annotated with prosodic information at both the phonetic and phonological levels (Garrido et al., 2013). It is a large compilation of speech (more than 25 hours recorded by 28 speakers) from various situational settings, namely, conversational speech, task-oriented speech and news reading, the latter being the source of speech samples for the present paper.

With the goal of gathering as much information as possible about the prosodic strategies that the broadcasters use to build a characteristic speech style, we will concentrate on the analysis of the patterns in stress, phrasing and intonation found in a part of the Glissando dataset of news in comparison with what is expected in citation forms. It is hypothesized that the professionals use special features in stress patterns, prosodic organisation and tonal representation, which enhance new information and aim to capture and maintain the listener's attention.

The paper is organized as follows. Section 2 reports on the procedure followed. Section 3 concentrates on the adjustments in prominence of the word patterns: phenomena of overaccentuation (3.1) and deaccenting (3.2) together with the resolution of stress clashes (3.3). Section 4 addresses the special features found in the phrasing strategies: the occurrence of unexpected pauses (4.1) and prosodic marking of initial edges (4.2) at the Intonational Phrase (IP) / intermediate phrase (ip) domains. Section 5 examines the most relevant tonal events that identify the typical chanting of broadcasters: a recurrent use of rises whose fundamental frequency $\left(f_{0}\right)$ peak coincides with the stressed syllable (5.1), a variety of non-falling pitch movements signalling intermediate phrasing (5.2), and the use of risingfalling pitch movements to signal ends in the utterance domain (5.3).

\section{PROCEDURE}

To examine the phrasal and tonal structure of the read speech of professional broadcasters, a subset of the Glissando corpus was annotated following the Sp_ToBI guidelines (Estebas-Vilaplana \& Prieto, 2010; Hualde \& Prieto, 2015). The following sections will give details about the corpus, the speakers, the recording conditions, and the labelling process.

\subsection{Corpus}

The corpus was excerpted from a part of the Glissando dataset of news. It consists of around 18 minutes of reading of 12 news stories recorded by two professional speakers (woman's voice: sp_f11r, and man's voice: sp_m09a). The main modality is declarative, with long sentences that include a variety of syntactic structures, such as parentheticals, subordinate clauses, or changes in word order (see the full description in EscuderoMancebo, Bonafonte, Aguilar, \& Garrido, 2009).

\subsection{Speakers}

As the rest of the Spanish speakers that recorded the Glissando corpus, the speakers (one male and one female) selected for this study use the variety of Spanish spoken in Valladolid, described as representative of standard European Peninsular Spanish (Penny, 2000), with an active use of the language in their personal and professional lives. Their ages were 34 and 46, and both had a wide experience in their professional field.

\subsection{Recordings}

All the recordings of the Glissando Spanish corpus took place in a soundproof room at the Audiovisual Media Service of the University of Valladolid. Recordings were made on a Marantz PMD670/W1B and a Marantz PMD560 recorders, using a Mackie CR1604-VLZ mixer, at a sampling frequency of $44 \mathrm{KHz}$, and a headset wireless microphone (Senheisser EW100-G2). In the recording sessions, the speakers were told to read the news texts as if they were on the air. 


\subsection{Labelling process}

The utterances were annotated by means of the ToBIbased annotation conventions to obtain information about prosodic phrasing (break tier: presence/absence of prosodic break and degree of strength of the break) and tonal representation (tone tier: significant tonal changes associated with pitch accents and with the end of prosodic units). A stress tier was added (Section 2.4.1) to mark the stress adjustments at the word domain, and a miscellaneous tier was used to annotate special features related to initial edges (Section 2.4.2).

All the speech data were manually labelled by the second author, a postgraduate student in linguistics with prior training in prosodic labelling. As in other ToBI systems, the procedure was perceptually based. That is, although the transcriber visualized a display of the signal $\left(f_{0}\right.$ curve and waveform together with the phonetic marks corresponding to words, syllables, and silences), she relied on her perceptual experience to make decisions on prosody. The annotation process was performed using Praat (version 6.0.40). The key elements to be labelled were prominence, prosodic boundary strength, pitch accent, and boundary tone types.

Given the phonological approach of the ToBI system, each language has developed its own proposal, Sp_ToBI in the case of Spanish (Beckman, Díaz-Campos, McGory, \& Morgan, 2002; Hualde \& Prieto, 2015; Prieto $\&$ Roseano, 2010). For the annotation of the Glissando corpus, representative of the Castilian Spanish variety, we followed the Sp_ToBI proposal in Estebas-Vilaplana and Prieto (2010), although some changes proposed in Hualde and Prieto (2015) consistent with the analysis of other Romance languages in Frota and Prieto (2015) were included: following these changes, the mid level (M) was tagged as '! $\mathrm{H}$ ' instead of ' $\mathrm{M}$ ', and the early rising accent was represented by ' $\mathrm{L}+<\mathrm{H}^{*}$ ' (instead of ' $\mathrm{L}+>\mathrm{H}^{*}$ '). Furthermore, the label ' $=$ ' proposed in Estebas-Vilaplana, Gutiérrez, Vizcaíno, and Cabrera (2015) was used to represent the tonal preservation in those cases of sustained pitch.

Other methodological points concern the special features found in the corpus of news reading: the labelling of stress (Section 2.4.1) and initial edges (Section 2.4.2).

\subsubsection{Labelling of stress}

To preserve the information about primary or secondary associations to lexical stress and the information about association and disassociation between the metrical tier and the autosegmental tier during the process of labelling, the procedure illustrated in Figure 1 was followed.

Besides the break tier and the tonal tier, a stress tier was used to mark the stress adjustments by means of an ad hoc code: the capital letter ' $\mathrm{T}$ ' specifies lexical stress at the syllable tier; the lowercase ' $t$ ' marks those cases of lexically unstressed syllables that were accented; the capital letter ' $T$ ' followed by the number ' 0 ' ( $T-0)$ signals those cases of accent removal.
Figure 1: Example of the labelling stress adjustments. The capital letter ' $T$ ' specifies lexical stress at the syllable tier; the lowercase ' $t$ ' marks those cases of lexically unstressed syllables that are accented. The capital letter ' $\mathrm{T}$ ' followed by the number

0 , that is, ' $\mathrm{T}-0$ ', signals those cases of accent removal.

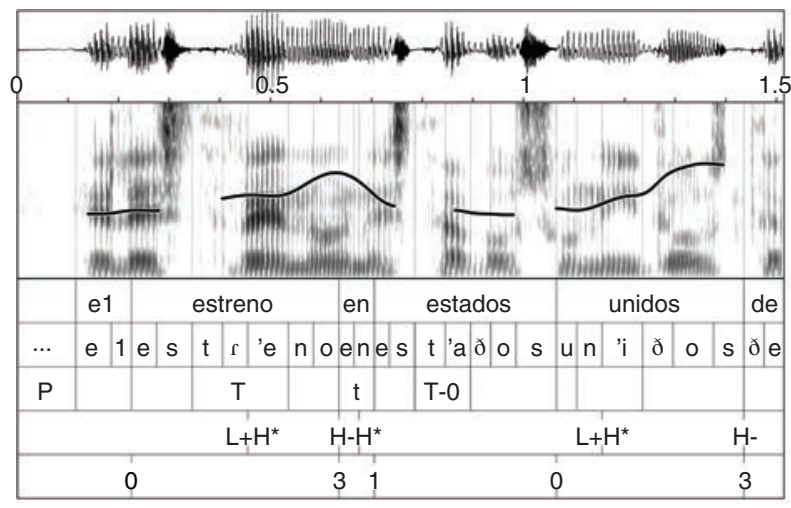

\subsubsection{Labelling of initial edges}

The miscellaneous tier was used to annotate two characteristics related to initial edges: pitch reset and the occurrence of a secondary stress on the initial syllable of the prosodic group. These two phenomena were distinguished considering the variation of the pitch height between the boundary tone of a prosodic group and the first high tone in the following group: if the difference was equal or higher than $10 \%$, the variation was labelled with the ad hoc tag 'PR'. This value (10\%) is considered the threshold of differential perception in intonation changes (Pamies Bertrán, Fernández Planas, Martínez Celdrán, Ortega Escandell, \& Amorós Céspedes, 2002; Rietveld \& Gussenhoven, 1985). ${ }^{1}$ If this threshold was not achieved, it was labelled as emphatic stress (ES).

The use of an initial boundary tone $(\% \mathrm{H})$ to explain a high-pitched beginning was dismissed since according to the ToBI guidelines (Beckman \& Ayers, 1997) it is justified only when there is no other possible explanation for the high-pitched beginning. The necessary condition to label a pitch height variation as an initial boundary tone is that the first word itself does not appear to be accented or when its accented syllable occurs too far into the word to account for the initial high target. That is, the label $\% \mathrm{H}$ should only be given when a high-pitched beginning for an utterance cannot be attributed to a $\mathrm{H}^{*}$ accent on the first few syllables in the utterance, and this is not the case in our news reading corpus.

Another characteristic that distinguishes an initial boundary tone from the emphatic marking of initial edges in news reading is that in the intonational analysis

\footnotetext{
1 In Frota, D'Imperio, Elordieta, and Prieto (2007), where a typology of boundary cues is compared for four Romance languages (Catalan, Spanish, Portuguese, and Italian), a ratio of 0.90 or higher between the first peaks of the first and second phrases was considered to indicate cases of pitch reset for Spanish and Catalan.
} 
assumed in the ToBI system, the initial boundary tone is limited to absolute utterance-initial position, whereas in the news reading a high-pitched beginning can also be found associated with an intermediate phrase.

\section{PROMINENCE}

Since it indicates different linguistic phenomena, such as accent patterns or contrastive focus, prominence in language can be conceived of from several dimensions: phonetic, phonological, semantic, pragmatic, etc. (Cole, 2015). In this study we consider that a syllable is prosodically prominent when it is perceived stronger than the rest of the syllables of a word within a sentence by a pitch accent.

Following Metrical Theory, stress is defined as metrical prominence of the word, phrase or utterance, whereas accent or pitch-accent is defined as "a clearly observable prominent $f_{0}$ movement, which consistently occurs in or near the stressed syllables of the key words" (Xu \& Xu, 2005, p. 181; see also Bolinger, 1986; Ladd, 2008; Liberman \& Prince, 1977). In stress languages, such as Spanish, stressed syllables serve as the landing site for accents, or, in other words, word-level stress and pitch-accent normally co-occur. Nevertheless, not all syllables with primary stress are accented in all contexts: the presence or absence of a pitch accent depends on the larger prosodic structure in which the lexical item is found. In pragmatically neutral sentences all content words are typically pitch accented, whereas functional words commonly occur in an unstressed form in connected speech (Navarro Tomás, 1925). Thus, three levels of syllabic prominence must be considered: unstressed, stressed and accented, and stressed but not accented (Ortega-Llebaria \& Prieto, 2007; Prieto \& Ortega-Llebaria, 2006).

In contrast to these generalizations, the following stress adjustments can be described in the analyzed corpus: the upgrading of unstressed syllables to accented syllables (Section 3.1), the stress shift to the word-initial syllable (Section 3.2), and the preservation of stresses in stress clash contexts (Section 3.3). Table 1 summarizes the data: of the 5112 unstressed syllables of the corpus, 279 were marked with an accent (i.e., unstressed but accented syllables), whereas out of a total of 1977 lexically stressed syllables, 100 did not bear a pitch accent (stressed and unaccented syllables).

\subsection{The upgrading of unstressed syllables to accented syllables}

Following Hualde (2007), we use the term postlexical secondary stress to mean prominence on a syllable other than the one that is lexically specified to carry word-level stress. When this prominence is assigned, it shows the usual correlates of accent in Spanish, including pitch excursions on those syllables (Ortega-Llebaria \& Prieto, 2011). In the news reading corpus, out of a total of 2156 syllables that bear pitch accent (out of a total of
Table 1: Data from the analysed corpus concerning stress and accent: total number of syllables of the corpus (N-S), number of stressed syllables that bear pitch accent (N-SAS: stressed and accented), number of stressed syllables that do not bear pitch accent (N-SUS: stressed and unaccented), number of unstressed syllables that do not bear pitch accent (N-UUS: unstressed and unaccented) and number of unstressed syllables that bear pitch accent (N-UAS: unstressed and accented).

\begin{tabular}{|l|r|r|r|r|r|}
\hline \multicolumn{2}{|c|}{} & \multicolumn{2}{c|}{$\begin{array}{c}\text { Stressed } \\
\text { syllables }\end{array}$} & \multicolumn{2}{c|}{$\begin{array}{c}\text { Unstressed } \\
\text { syllables }\end{array}$} \\
\hline Speaker & N-S & N-SAS & N-SUS & N-UUS & N-UAS \\
\hline f11r & 3596 & 916 & 61 & 2427 & 192 \\
\hline m09a & 3493 & 961 & 39 & 2406 & 87 \\
\hline & 7089 & 1877 & 100 & 4833 & 279 \\
\hline
\end{tabular}

Table 2: Data from the analysed corpus concerning types of secondary stresses: number of accented syllables in the corpus (N-AS), number of stressed syllables that bear pitch accent (N-SAS; stressed and accented syllables), number of unstressed syllables that do not bear pitch accent (N-UAS; unstressed and accented syllables), number of cases of emphatic stress (N-ES), number of cases with rhythmic stress that occur in word-initial position (N-RSWI), and number of cases with rhythmic stress in non word-initial position (N-RSNWI).

\begin{tabular}{|l|c|c|c|c|c|c|}
\hline Speaker & N-AS & N-SAS & N-UAS & N-ES & $\begin{array}{c}\text { N- } \\
\text { RSWI }\end{array}$ & $\begin{array}{c}\text { N- } \\
\text { RSNWI }\end{array}$ \\
\hline f11r & 1108 & 916 & 192 & 172 & 48 & 18 \\
\hline m09a & 1048 & 961 & 87 & 82 & 18 & 3 \\
\hline & 2156 & 1877 & 279 & 254 & 66 & 21 \\
\hline
\end{tabular}

7089 syllables in the corpus) - in Table 2, see the figures corresponding to N-AS-, 279 pitch accents are linked to lexically unstressed syllables (N-UAS in Table 2). Therefore, a coincidence between lexical stress and pitch accent is found in $87 \%$ of the total of cases (1877 stressed syllables that bear pitch accent, N-SAS in Table 2), leaving many tones that must be explained by the placement of secondary stress. In other words, the general statement that unstressed syllables are unaccented does not apply to the reading news style.

Interestingly, the size of the corpus allows us to observe two conditions on the placement of the secondary stresses: the number of syllables of the word (one, two, and three or more) and the position of the syllable in the word (initial, medial, final).

Polysyllabic words, which are expected to bear only one lexical stress in neutral speech, show a common process of stress addition in the news corpus: of those 279 secondary stresses, 89 were found in words with three or more syllables, and they were situated only one syllable far from the surrounding accents, which 
could be interpreted as a tendency to a trochaic rhythm, reinforced by the fact that the most common word pattern in Spanish is bisyllabic with the lexical stress in the penultimate syllable (paroxytone pattern) ${ }^{2}$ (Quilis, 1983). However, the most relevant feature in the corpus of news reading is the occurrence of additional stress in functional monosyllabic words, which in Spanish are usually unstressed (except if they are pronounced in isolation) and form with the lexical word a clitic group (Navarro Tomás, 1925). Thus, out of 279 cases of unstressed accented syllables, 187 were found in functional unstressed monosyllabic words. What is significant about the relation between lexical stress and accent is that the placement of an accent does not correspond to the distinction between function and content words and that the prosodic make-up of the sentence is modified.

Concerning the location of secondary stress with respect to word boundaries, two types can be distinguished according to Hualde (2007): rhythmic stress and emphatic word-initial stress. Rhythmic stress consists in placing stress two syllables before the syllable with lexical stress, whereas emphatic word-initial stress is situated on the initial syllable of the word showing a delimitative function. Both types of secondary stress are characterised by a tonal peak associated with the syllable, that is, they are pitch accents. What is found in the analysed corpus is that both types coincide in the majority of the cases, as shown in Table 2, where the number of occurrences of the accented syllables (stressed or unstressed) is distributed depending on the type of secondary stress (emphatic stress, rhythmic stress in word-initial position, or rhythmic stress in non wordinitial position): 66 of those cases labelled as rhythmic occur in word-initial position. This overlap explains that the sum of emphatic plus rhythmic cases exceeds that of unstressed syllables that bear pitch accent. Out of the 279 unstressed accented syllables (Table 2), 254 correspond to emphatic stresses (that is, word-initial stresses), and among these 254 cases, 66 cases are placed two syllables before the syllable with lexical stress, in word-initial position. It is inferred from this data that the initial position in the word is the main factor that explains the upgrading of unstressed syllables to accented ones in the news corpus, and that the occurrence of a pitch accent in the initial syllable of the word works as a delimiter.

Figure 2 is a good example of the stress addition in polysyllabic words with this delimitative function. The word dimensiones ('dimensions') illustrates how rhythmic stress can be at the same time emphatic stress. Since the word-initial accent is situated in the first syllable of the word, it can be interpreted as an emphatic stress, whereas the syllable interval between each accent indicates the existence of a rhythmic stress.

2 Spanish does not have a fixed word stress pattern: the stress can appear in the ultimate, penultimate, or antepenultimate syllable, usually known as oxytone, paroxytone, and proparoxytone patterns, respectively.
Figure 2: Illustration of the upgrading of unstressed syllables to accented ones in the fragment también en tres dimensiones ('also in three dimensions').

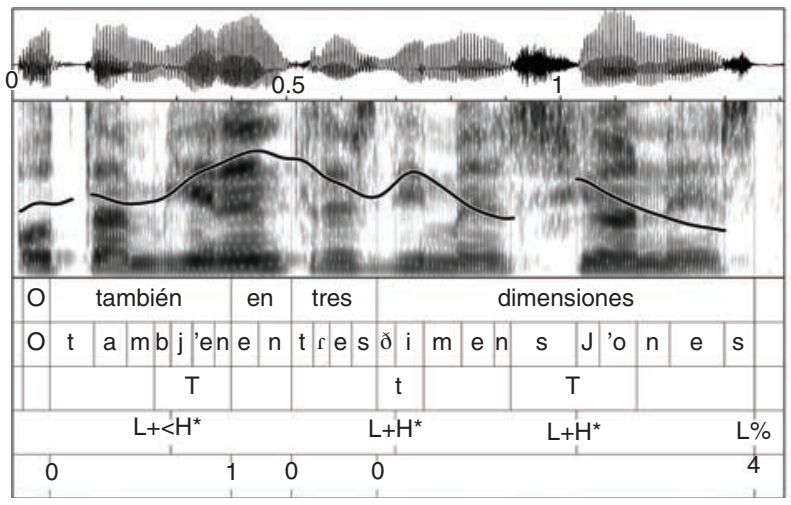

\subsection{Stress shift for the benefit of the word boundary}

The corpus of news reading shows instances of deaccenting, but in contrast to what is found in non-read speech (Face, 2008, counts a 30\% of accentable syllables that do not show tonal excursions), its frequency of occurrence is very low: as shown in Table 1, of those 1977 lexically stressed syllables of the corpus, 100 do not bear a pitch accent. The noteworthy event is that in the news corpus it always correlates with a shift of the accent to the wordinitial syllable. Figure 3 exemplifies this process: in the sequence de una joven mortal ('of a young mortal girl'), the oxytone word mortal, whose lexical stress should appear in the final syllable, is produced with the stress in the word-initial syllable, which also agrees with the oneto-one alternation between stressed and unstressed syllables. Although the distance between word stresses in the resulting structure suggests a preference for the trochaic rhythmic pattern, the stress shift favours the beginning of the word.

Another interesting issue related to the stress removal phenomena is the reduction in prominence of utterancemedial words. As Ortega-Llebaria and Prieto (2007) notice, parentheticals are produced with lower degrees of

Figure 3: Illustration of stress shift. It depicts the intonational characteristics of the fragment de una joven mortal ('of a young mortal girl').

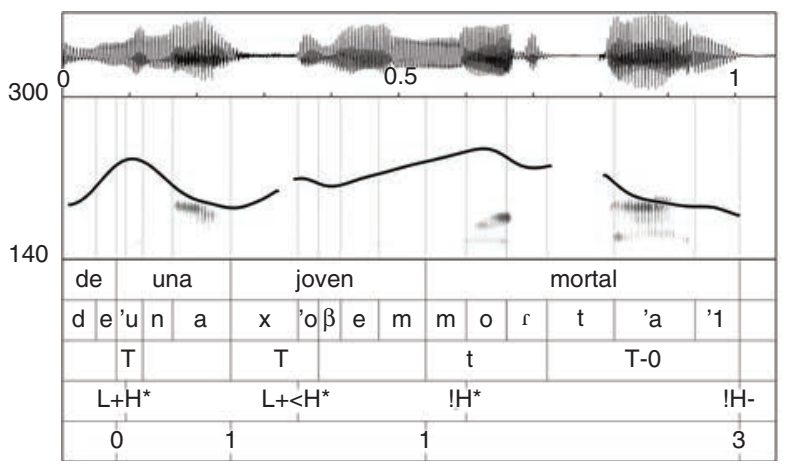


stress than the main clause to which they are attached, often without any pitch accents. Their findings show that some level of stress on lexically stressed syllables is preserved, but that stress reduction can also be complete in this context. Additionally, the results from the production and perception experiments in Torreira, Simonet, and Hualde (2014) demonstrated that in the absence of pitchaccented words in phrase-medial position in Spanish, duration and intensity cues of lexical stress are produced by speakers and used by listeners above chance level.

Nevertheless, the absence of intonational pitch accents in phrase-medial position is not the tendency found in the Glissando news subcorpus. There are some cases of tonal subordination, such as the one depicted in Figure 4, where the stretch corresponding to a relative clause (que se puede hacer en linea 'which can be done online') shows a fall in the global pitch scaling compared with the tonal range of the rest of the utterance, but the most common intonational pattern is what appears in Figure 5, i.e., falls and rises that are situated along the whole utterance regardless of the syntactic properties of the groups.

\subsection{Resolution of stress clashes}

This subsection discusses the effects of strict adjacency between two lexically stressed syllables (stress clash context) on the phonetic realization of these stresses in the analysed corpus. In general, speakers resolve stress clash situations through two prosodic strategies: a) avoidance, by means of stress removal to avoid placing accents in adjacent syllables; b) tonal clash, which can be resolved by anticipating the first tonal gesture or delaying

Figure 4: Illustration of tonal subordination. It depicts the intonational characteristics of an intonational phrase (ip) fragment, a subordinate clause (que se puede hacer en linea 'which can be done online'), and characteristics relative to the tonal height of the preceding (el test 'the test') and following (ha sido desarrollado por 'it was developed by') groups.

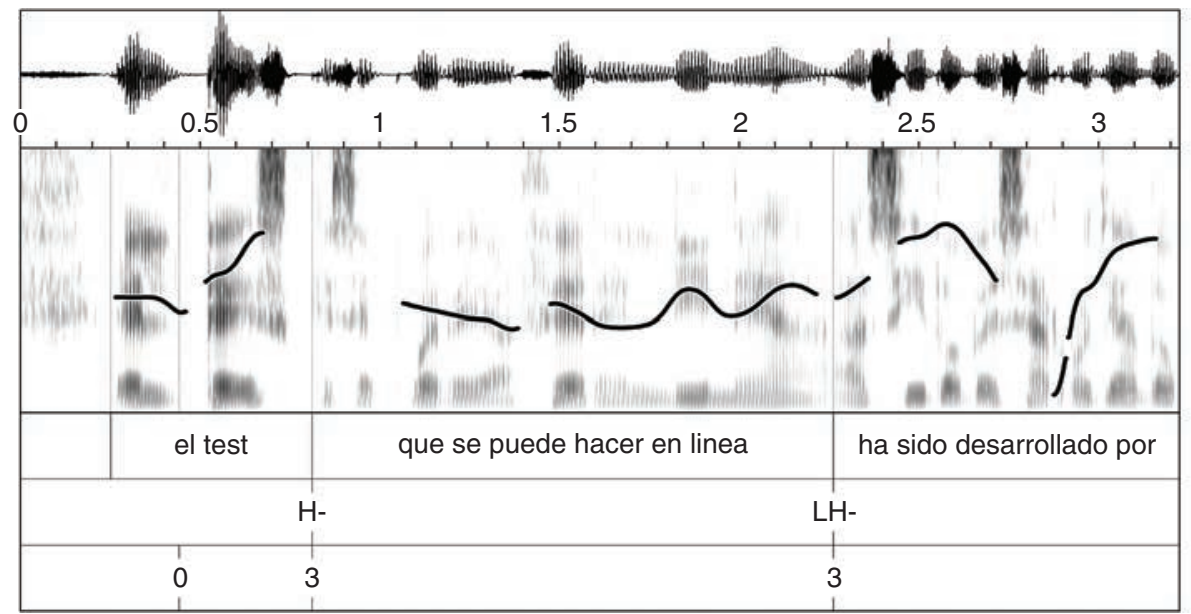

Figure 5: Illustration of the most common pattern in radio news: non-tonal subordination. It depicts falls and rises along the whole utterance regardless of syntactic or prosodic subordination according to the chanting style of news broadcasters (los autores aconsejan a quien le salga un resultado superior que, si está preocupado, acuda a su médico 'the authors advise whoever gets a higher result, if he/she is worried, to see his/her doctor').

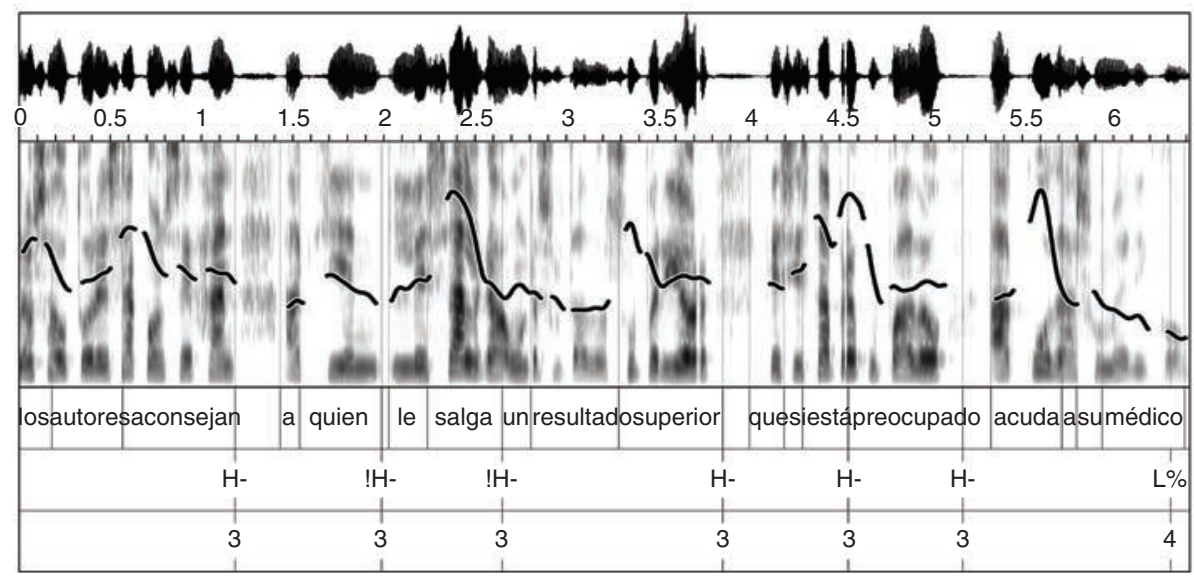


Figure 6: Illustration of two strategies to solve stress clashes. It depicts the intonational characteristics of the same fragment of the news corpus no hay este fin de semana ('there is not this weekend') read by the two speakers (female and male, respectively).

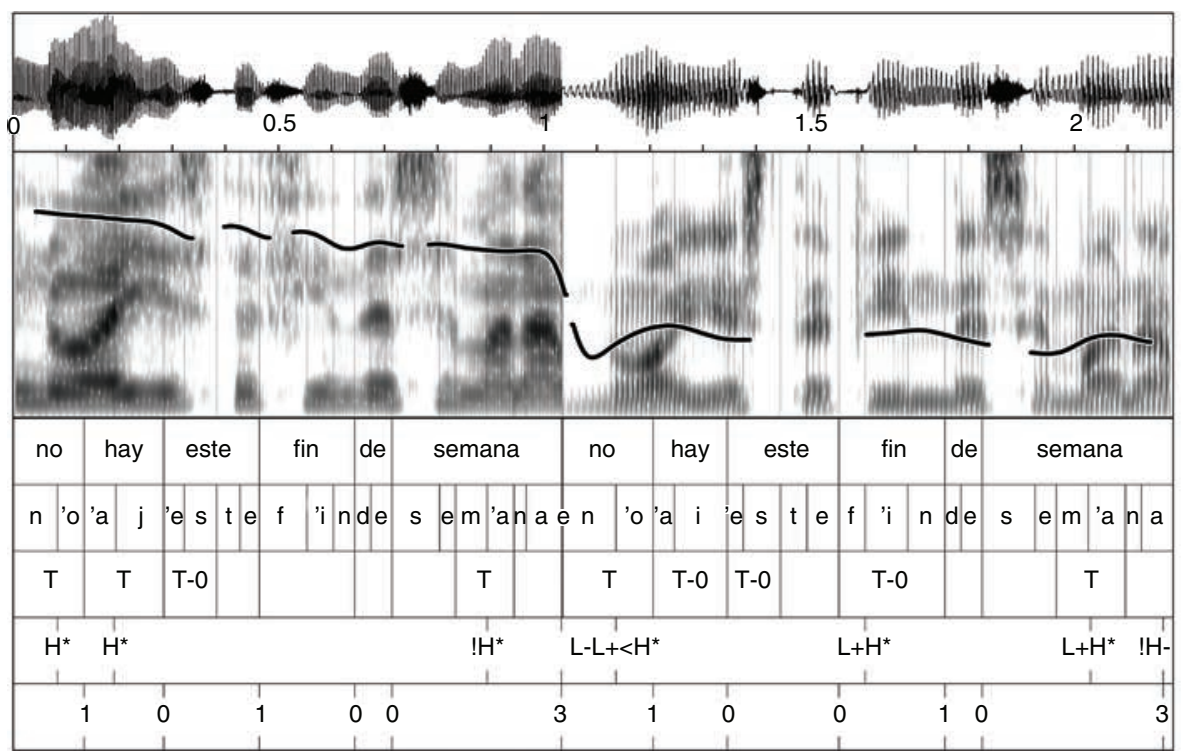

the second one (Arvaniti, 1994; Farnetani \& Kori, 1983; Prieto, 2005).

As is common in prosody, optionality must be considered in the resolution of stress clashes. Speakers can choose between the avoidance of strict adjacency of pitch accents and the maintenance of the accents as if the words were pronounced in an isolated way. For example, the sequence of three lexically stressed syllables in the same fragment no hay este fin de semana ('there is not this weekend') is produced differently by each speaker (Figure 6). In the production of the first, the adjacent pitch accents (['no.'ai..] are fully maintained and realized with high tones $\left(\mathrm{H}^{*}\right)$, while the stressed syllable ['es] is deaccented. In that of the second, the same sequence of three word stresses (['no.'ai.'es]) is resolved by means of deaccenting the stresses situated to the right and placing the prominence in the first word stress ['no]. In this case, the associated tone is a bitonal pitch accent with low tone followed by high tone prominence, that is, a rising accent whose $f_{0}$ peak coincides with the post-stressed syllable: $\mathrm{L}+<\mathrm{H}^{*}$.

Nevertheless, tonal preservation is the most common option (Table 3), where the full phonetic realization of adjacent stresses represents more than half of the cases $(55.3 \%)$. Figure 7 illustrates this strategy with two examples of maintenance of word stresses, regardless of their adjacency: hoy llega ('he/she arrives today'), se podrá ver de ('one will be able to see of'). The adjacency of pitch accents causes a tonal repulsion that prevents the displacement of the $f_{0}$ peak in a context where a $\mathrm{L}+<\mathrm{H}^{*}$ would be expected. The space left by the diphthong in the first example, hoy llega ['oi'Keya], allows the low tone to be present in the phonetic realization, whereas when the syllabic nucleus is a full vowel, podrá ver [po'ora'ßer], the fall between the high tones is not perceived.
Table 3: Number of cases $(\mathrm{N})$ regarding the resolution of strict adjacency between two accents in the analysed corpus.

\begin{tabular}{|l|c|c|c|}
\hline & $\begin{array}{c}\text { Stress } \\
\text { removal }\end{array}$ & $\begin{array}{c}\text { Tonal } \\
\text { clash }\end{array}$ & $\begin{array}{c}\text { Tonal } \\
\text { preservation }\end{array}$ \\
\hline $\mathrm{N}$ & 19 & 19 & 47 \\
\hline
\end{tabular}

Figure 7: Illustration of preservation of adjacent stresses. It depicts the intonational characteristics of two fragments, hoy llega ('it arrives today') and se podrá ver de ('one will be able to see of').

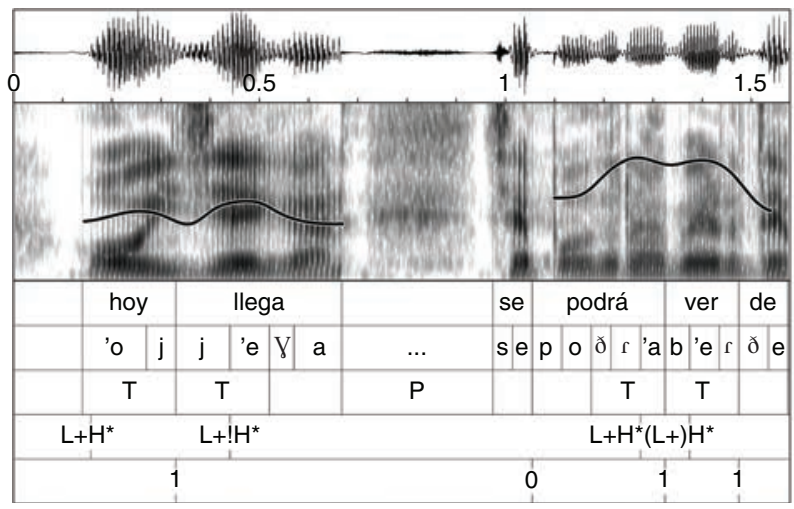

\section{PROSODIC PHRASING}

This section concentrates on two characteristics of prosodic organization found in the corpus of news read by professional broadcasters: strategically placed silences that enhance the prosodic units that offer new information (Section 4.1), and the prosodic marking of initial edges of 
groups, which captures and preserves the listener's attention (Section 4.2).

\subsection{Pauses that enhance the prosodic units that highlight information}

As a rule, according to the hierarchy of prosodic groups and the subsequent definition of break indices in Sp_ToBI $($ BI3 = end of an intermediate phrase; BI4=end of an intonational phrase), what is expected in the process of labelling is the appearance of a pause after BI4, signalling the end of an utterance, with complete sense, and the absence of a pause after BI3, indicating that not all the information has been given. On the contrary, data coming from the Glissando news subcorpus show that in 320 cases out of a total of 811 , a silence is found after the prosodic intermediate break (BI3). It is true that some intermediate phrases can be autonomous, such as parentheticals or adjuncts, and that sentences in the news corpus are long (see Garrido et al., 2013, for a complete description), but these facts do not cover a high number of cases.

In Spanish descriptions (Canellada \& Madsen, 1987; Marín, Aguilar, \& Casacuberta, 2002; Quilis, 1993), syntactic dependency on pausing has been explained by means of a set of combinations of categories between which no pause can appear, for instance: adjective-noun, noun-adjective, verb-adverb, adverb-verb, adverb-adjective, adverb-adverb, determiner-noun, determiner-adjective, elements in collocations. From another point of view, the use of phonological domains such as the phonological phrase establishes the correspondence between the word level and syntactic constituents (Nespor \& Vogel, 1994 [1986]; Sosa, 1999).

In our corpus, the location of pauses in contexts that are not guided by syntactic or prosodic constraints can only be explained by the aim of capturing the attention of the listener over the piece of information that comes after a pause. Figure 8 presents an example of the pragmatic function of pauses that takes place in non-expected positions if compared with unmarked reading styles. Although in a neutral reading the pause between the verb and the locative complement en Kenia ('in Kenia') wouldn't be

Figure 8: Illustration of pauses in unexpected positions. It shows a silence after BI3 in también el lunes se reunen en Kenia ('also on Monday they meet in Kenia').

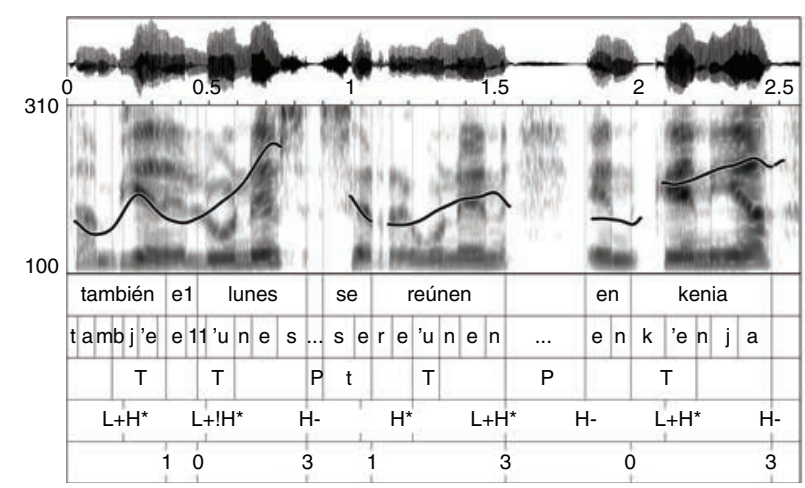

made, the pre- and post-pauses enclose the information that the reader wants to highlight. The relevance of the information is also underlined by the tonal configuration $\mathrm{L}+\mathrm{H}^{*} \mathrm{H}$-, an ascending tonal movement that confers the status of non-finality to the constituent (see later Section 5.2). In English, non-finality has been associated with a rising boundary tone $\left(\mathrm{L}^{*} \mathrm{H}-\right)$ at the rightmost edge of an intonation phrase to express that the information contained therein is to be understood as closely related to what comes next in the discourse (Pierrehumbert \& Hirschberg, 1990). Likewise, in Spanish, a rising movement at the end of a minor prosodic constituent is also a cohesive device linking discourse elements (Hualde, 2002), as in the case of an edge between a subject and its predicate (i.e., rama tensiva, 'tensile branch', Navarro Tomás, 1944). The rising boundary tone (H-) indicates that there exists additional information to complete the utterance, and the silence enhances the unit that is going to be pronounced.

\subsection{Prosodic marking of initial edges}

A common tonal feature in our corpus is the emphatic marking of the beginning of a prosodic unit, either an ip or an IP. The perceptual salience of the first syllable (or syllables) of the new group is phonetically realised by means of the placement of a secondary stress that can eventually trigger a pitch reset. The main difference we are dealing with is that the occurrence of a secondary stress at the beginning of the group functions as a word-delimiter with emphatic function and depends on the tonal range of the speaker, while the pitch reset is identified with respect to the previous prosodic group (that is, there is a contextual tonal effect that blocks the fall of the declination line and allows the speaker to reset his or her tonal scaling). Figures 9 and 10 illustrate these two prosodic strategies.

Figure 9 displays a high-pitched beginning of an ip by means of the placement of a secondary stress at the initial syllable of the group [que compara los precios] ('which compares the prices'). Although the initial syllable of the group, [ke], has been stressed and accented, the variation in the height of the pitch accent's $f_{0}$ peak assigned to it does not exceed the threshold of $10 \%$ with respect to the height of the last high tone of the preceding group ( $\mathrm{L}+<\mathrm{H}^{*}=296 \mathrm{~Hz}$ and $\mathrm{H}-=299 \mathrm{~Hz}$, respectively). The same can be said of the following ip [en función del producto] ('depending on the product').

The prosodic marking of initial edges with pitch reset can be found either after a high $(\mathrm{H}-)$ or a mid $(! \mathrm{H}-)$ boundary tone, as shown in the two independent examples excerpted from the corpus in Figure 10. The first example [de poemas] [y también] ('of poems' 'and also') illustrates the typical continuation rise at the end of an intermediate break; what must be highlighted now is that the unstressed monosyllabic functional word $y$ ('and') is upgraded to an accented syllable, and additionally, the pitch range is reset, since a difference greater than $10 \%$ is found between the two adjacent high tones $(\mathrm{H}-=187 \mathrm{~Hz}$; $\left.¡ H^{*}=296 \mathrm{~Hz}\right)$. Similarly, the pitch height of the boundary 
Figure 9: Illustration of a high-pitched beginning of an intermediate prosodic group by means of the placement of a secondary stress at the initial syllable. It shows an emphatic stress (ES) at the initial edge of each ip in the stretch proyecto que compara los precios en función del producto ('project that compares the prices depending on the product').

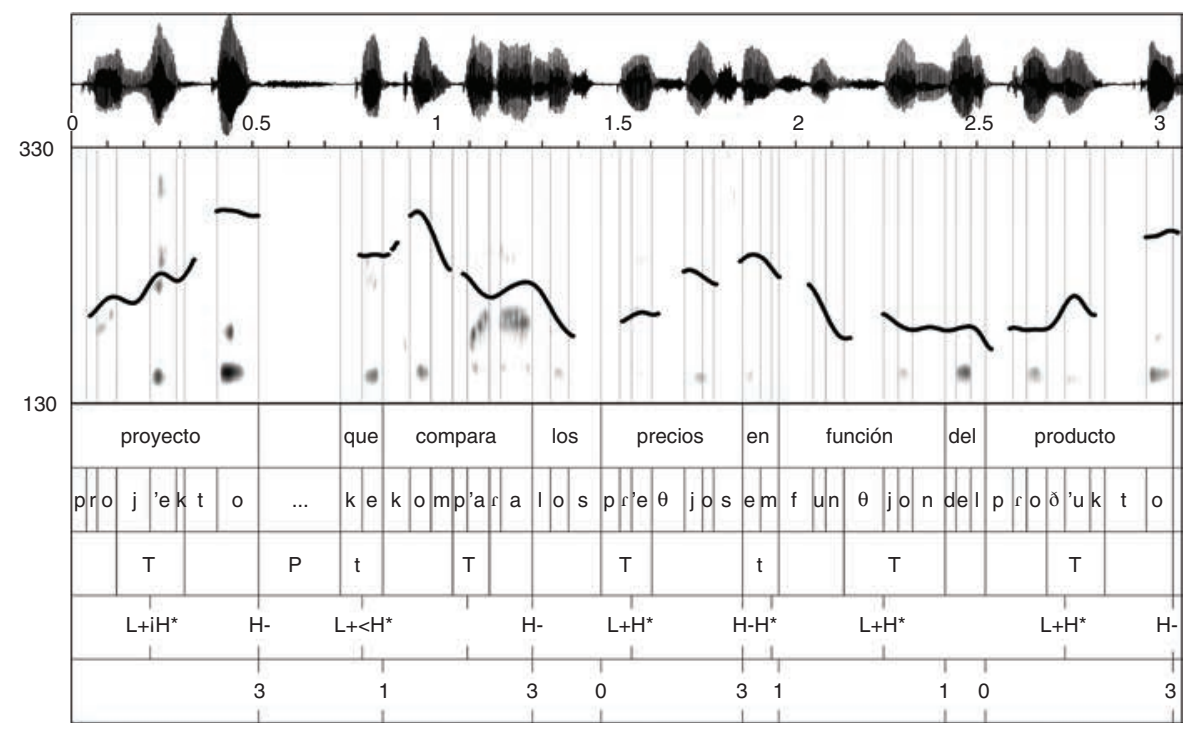

Figure 10: Illustration of a case of pitch reset. It depicts the intonational characteristics of two independent fragments of the corpus: de poemas y también ('of poems and also') and ([las cestas] tienen que rellenarse con productos asequibles ('[baskets] must be filled with affordable products') with pitch reset in the functional words $y$ and con ('and', 'with').

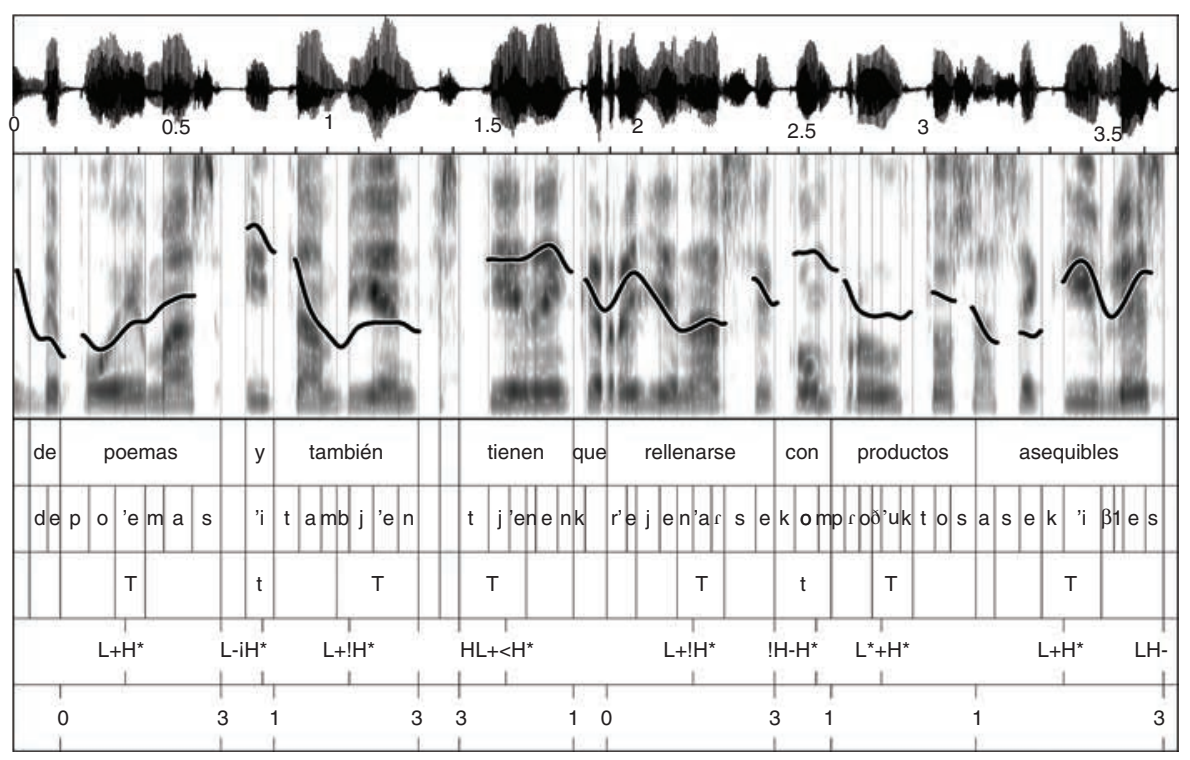

tone in the example [tienen que rellenarse] ('must be filled') followed by [con productos asequibles] ('with affordable products') appears in a lower tonal range with respect to the one of the immediately following high pitch accent $\left(! \mathrm{H}-=187 \mathrm{~Hz} ; \mathrm{H}^{*}=239 \mathrm{~Hz}\right)$.

The prosodic marking of the initial edge is conveyed by the placement of a secondary stress, that is, a more prominent syllable than the surrounding syllables (with or without pitch reset). Moreover, the emphatic marking can appear at the beginning of a new IP, but also at the beginning of an ip. In all cases, the purpose of what is communicated by the high tone is to gain or to preserve the attention of the hearer. Related to this, what would be expected is that the prosodic marking of a new IP would always be accompanied by a pitch reset, in contrast to the prosodic marking of an ip, without pitch reset. Nevertheless, the analysis of the data does not support this hypothesis: of 58 cases of high-pitched cases beginning with pitch reset, 23 are found after a BI4 and 35 after a BI3. 
Additionally, in the analysed corpus of news texts the types of pitch movements associated with the initial syllable of a prosodic group (IP or ip) are not limited to high $\left(\mathrm{H}, ! \mathrm{H},{ }_{i} \mathrm{H}\right)$, but also rising accents can be found $\left(\mathrm{L}+\mathrm{H}^{*}\right.$, $\left.\mathrm{L}+<\mathrm{H}^{*},(\mathrm{~L}+) \mathrm{H}^{*}\right)$, supporting the difference with respect to the initial boundary tone, which is restricted to the high tone $\% \mathrm{H}$ (Section 2.4.2).

\section{TONAL REPRESENTATION}

This section is devoted to the presentation of the most relevant tonal events identified in the analysis of the corpus: a recurrent use of rises accounted for by $\mathrm{L}+\mathrm{H}^{*}$ (Section 5.1), a variety of non-falling pitch movements signalling intermediate phrasing (Section 5.2), and the use of rising-falling pitch movements to signal ends (Section 5.3). We will concentrate on those pitch movements that are unexpected if compared with a neutral reading style, according to previous studies of Spanish prosody (Alcoba \& Murillo, 1998; Face, 2008; NavarroTomás, 1944; Sosa, 1999; among others).

\subsection{Use of rises accounted for by $L+H^{*}$}

In Spanish, three types of rising accents can be described: a) a bitonal pitch accent with low tone followed by high tone prominence whose $f_{0}$ peak coincides with the stressed syllable $\left(\mathrm{L}+\mathrm{H}^{*}\right)$; b) a bitonal pitch accent with low tone followed by high tone prominence whose $f_{0}$ peak coincides with the post-stressed syllable $\left.\left(\mathrm{L}+<\mathrm{H}^{*}\right) ; \mathrm{c}\right)$ a bitonal pitch accent with low tone prominence followed by high tone whose $f_{0}$ peak coincides with a post-stressed syllable $\left(\mathrm{L}^{*}+\mathrm{H}\right)$. The unmarked pitch accent is the rising accent with peak delay $\mathrm{L}+<\mathrm{H}^{*}$, while the absence of peak delay is commonly found in the nuclear position of narrow focus statements, counterexpectational yes-no and wh-questions, statements of the obvious, commands, and vocatives (Estebas-Vilaplana \& Prieto, 2010; Face \& Prieto, 2007).

In line with previous studies on news reading by professionals (cf. de-la-Mota \& Rodero, 2011; Rodero Antón, 2013), what is found in the analysed news corpus is a repeated occurrence of rising accents whose $f_{0}$ peak coincides with the stressed syllable, both in nuclear and prenuclear positions. Out of a total of 2156, 1502 correspond to cases of rising accents without peak delay $\left(\mathrm{L}+\mathrm{H}^{*}\right.$, including the upstepped and downstepped variants; $69 \%$ of the total of pitch accents), and 767 of them appear in prenuclear position.

Figure 11 is a good illustration of the tendency towards the occurrence of $\mathrm{L}+\mathrm{H}^{*}$. In all the stressed syllables of the sentence también se codean con la música improvisada ('they also socialize with the music that has been improvised'), the $f_{0}$ peak is within the stressed syllable in ['Bien] (también 'also'), ['ðe] (se codean 'they socialize'), ['mu] (música 'music'), ['sa] (improvisada 'improvised'). In Spanish, in an unmarked style of reading the expected pitch accent in those contexts (broad focus) would be a rising accent with peak delay, that is, $\mathrm{L}+<\mathrm{H}^{*}$, but the emphatic style of broadcasters triggers the interpretation of a context of narrow focus almost on every word, which explains the use of $\mathrm{L}+\mathrm{H}^{*}$. Assuming that the absence of peak delay is a marked tonal configuration, the data detailed in Table 4 certify the trend to the emphatic style of professional speakers. Moreover, the recurrent use of $\mathrm{L}+\mathrm{H}^{*}$ leads to a variety of non-falling tunes signalling intermediate phrasing (Section 5.2) and to the repeated pattern of rising-falling tunes to points that are ends of utterances (Section 5.3).

Figure 11: Illustration of the recurrent use of $\mathrm{L}+\mathrm{H}^{*}$ in a fragment of the corpus: también se codean con la música improvisada ('they also socialize with the music that has been improvised').

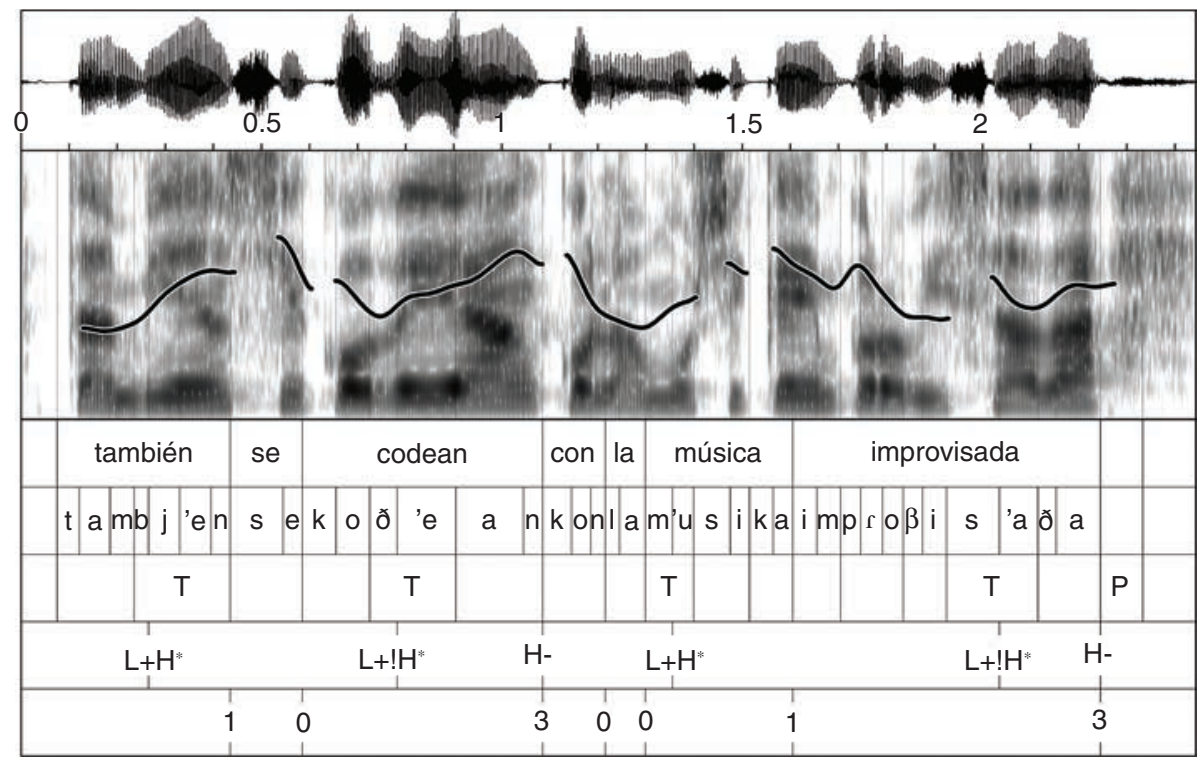


Table 4: Number of cases of each type of pitch accent in prenuclear and nuclear positions.

\begin{tabular}{|l|c|c|}
\hline Tonal category & $\begin{array}{c}\text { N in prenuclear } \\
\text { position }\end{array}$ & $\begin{array}{c}\text { N in nuclear } \\
\text { position }\end{array}$ \\
\hline $\mathrm{L}+\mathrm{H}^{*}$ & 566 & 494 \\
\hline $\mathrm{L}+! \mathrm{H}^{*}$ & 148 & 171 \\
\hline $\mathrm{L}+\mathrm{H}^{*}$ & 53 & 70 \\
\hline $\mathrm{L}+<\mathrm{H}^{*}$ & 254 & 0 \\
\hline $\mathrm{L}+<! \mathrm{H}^{*}$ & 15 & 0 \\
\hline $\mathrm{H}^{*}$ & 145 & 36 \\
\hline$! \mathrm{H}^{*}$ & 47 & 51 \\
\hline $\mathrm{iH}^{*}$ & 15 & 0 \\
\hline $\mathrm{L}^{*}$ & 14 & 72 \\
\hline $\mathrm{L}^{*}+\mathrm{H}$ & 4 & 0 \\
\hline $\mathrm{H}+\mathrm{L}^{*}$ & 0 & 1 \\
\hline
\end{tabular}

\subsection{Variety of non-falling tunes signalling intermediate phrasing}

It is generally acknowledged that prosodic intermediate breaks convey a non-finality interpretation reinforced through pitch configurations that are rich and varied. From the pioneering work of Navarro Tomás (1944) a set of tunes for Spanish (low-to-high, mid-tolow, low-to-mid, high-to-mid, and sustained pitch) is related to the degrees of cohesion or strength between groups. According to Navarro Tomás, the strongest opposition between prosodic groups is conveyed by a low-to-high tone (anticadencia), which signals the end of the theme part of an utterance (in declaratives), or by a mid-to-low tone (cadencia), located at the end of the rheme (also in declaratives). The other three tones attested by Navarro Tomás, namely, low-to-mid (semianticadencia), high-to-mid (semicadencia), and sustained (suspensión) express weaker cohesion degrees among the intonation phrases.

Accordingly, the typical tunes that express non-finality in $\mathrm{Sp}$ ToBI are H- (high, continuation rise), ! H- (mid), LH- (low-to-high), L!H- (low-to-mid) and $=$ - $(\text { sustained })^{3}$, whereas the typical tune to express finality is $\mathrm{L} \%$.

As shown in Gutiérrez González and Aguilar (2015), there is a correspondence between the type of boundary tone and the degree of strength of the break since there is a clear trend to associate those boundary tones that provide a non-finality sense with a minor break (BI3), and to associate the low boundary tone, which indicates the end of an utterance or a complete sense, mainly with major breaks (BI4). Nevertheless, some intermediate phrases end with a low tone (L-BI3). In general, these cases correspond to adjuncts or parentheticals,

\footnotetext{
3 This boundary tone keeps the previous tone value. Represented in previous proposals as HL- (Prieto \& Roseano, 2010), its representation has been replaced to account for tonal preservation (cf. EstebasVilaplana et al., 2015).
}

with syntactic and prosodic independence, but without semantic/pragmatic autonomy, although the low tone can appear in a position where a continuation rise is expected-for instance, after a member of an enumeration and between a subject and its predicate, as shown in Figure 12-. What is relevant in those cases is that the nuclear pitch accent is never a low tone $\left(\mathrm{L}^{*}\right)$, but instead a rising tone: if we compare the pitch configurations with L- in Tables 5 and 6 it is inferred that the typical tune to indicate the end of an utterance is $\mathrm{L}^{*} \mathrm{~L} \%$, while other types of falling contours $\left(\mathrm{L}+\mathrm{H}^{*} \mathrm{~L}-\right.$, $\left.\mathrm{L}+! \mathrm{H}^{*} \mathrm{~L}-, \mathrm{H}^{*} \mathrm{~L}-\right)$ are representative of the emphatic style of broadcasters, or typical chanting style, in which melodic contours overlap the statements, often irrespective of their semantic content.

We will now consider the contribution of the pitch accents to the types of nuclear contours that we have found in the corpus associated with an intermediate boundary (BI3): continuation rise, fall-to-mid patterns, fall-rise patterns, and sustained pitch (Table 5). Based on our data, the dominant nuclear accent involves a rising accent $\mathrm{L}+\mathrm{H}^{*}$ (609 instances out of 696 , including upstepped and downstepped variants), although instances of $\mathrm{H}^{*}$ (with upstepped or downstepped variants) are also found. These data differ from those offered in Frota et al. (2007) for Spanish, where two types of rising accents were found $\left(\mathrm{L}^{*}+\mathrm{H}\right.$ and $\left.\mathrm{L}+\mathrm{H}^{*}\right)$ followed by a continuation rise, and supports the idea that the chanting style of professional broadcasters is a specific genre of speech.

\subsubsection{Continuation rise}

A continuation rise indicates a rising outline after a rising pitch accent $\mathrm{L}+\mathrm{H}^{*}$ or $(\mathrm{L}+) \mathrm{H}^{*}$, as the two instances in Figure 13 exemplify. In the first example, the continuation rise separates the first member of the enumeration from the other two (como alubias, garbanzos y judias 'such as pinto beans, chickpeas, and green beans'). In the second, the continuation rise appears before a pause - as said in Section 4.1, in the analysed corpus the occurrence of a pause after a BI3 is very common-and it connects a locative complement with an instrumental argument.

\subsubsection{Fall-to-mid pattern}

The mid level at the edge of an intermediate prosodic group (!H-) indicates a descent to a mid tone from a rising pitch accent with non-delayed peak, that is, $\mathrm{L}+\mathrm{H}^{*}$ or $\left(\mathrm{L}+\mathrm{H}^{*}\right.$. Depending on the speaker's tonal range, the equivalence to a mid tone can be located at a different level between high and low. In any case, the mid value does not depend on the previous values of the target $\mathrm{H}$ in the utterance, but functions as a tonal category in Spanish. The results of a production test conducted by Estebas Vilaplanas (2009) provided evidence of the existence of four phonological targets at sentence-final position in Spanish. The acoustic cues of the boundary tones in a 
Figure 12: Illustration of L- combined with BI3. It depicts the intonational characteristics of $y$ aunque PNV e Izquierda Unida se han quejado ('and although PNV [proper noun] and Izquierda Unida [proper noun] have complained').

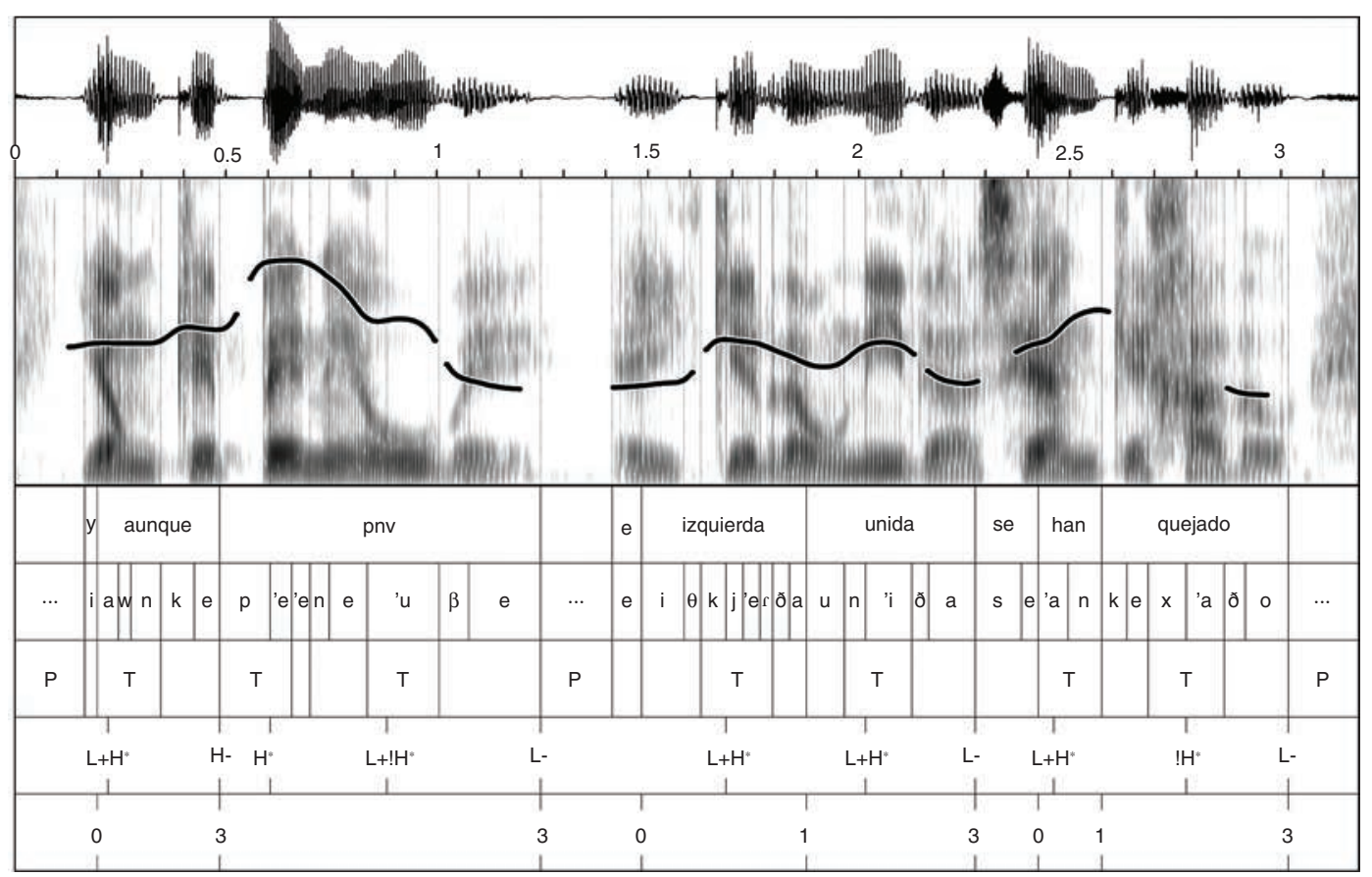

Table 5: Number of cases $(\mathrm{N})$ of tonal contours at the end of an intermediate phrase (BI3).

\begin{tabular}{|c|l|}
\hline N BI3 & Tonal contours \\
\hline 199 & $\mathrm{~L}+\mathrm{H}^{*} \mathrm{H}-$ \\
\hline 74 & $\mathrm{~L}+! \mathrm{H}^{*} \mathrm{H}-$ \\
\hline 31 & $\mathrm{~L}+{ }^{*} \mathrm{H}^{*} \mathrm{H}-$ \\
\hline 13 & $\mathrm{H} \mathrm{H}^{-}$ \\
\hline 11 & $! \mathrm{H}^{*} \mathrm{H}-$ \\
\hline 128 & $\mathrm{~L}+\mathrm{H}^{*} ! \mathrm{H}-$ \\
\hline 10 & $(\mathrm{~L}+) \mathrm{H}^{*} ! \mathrm{H}-$ \\
\hline 23 & $\mathrm{~L}+\mathrm{H}^{*} ! \mathrm{H}-$ \\
\hline 47 & $\mathrm{~L}+! \mathrm{H}^{*} ! \mathrm{H}-$ \\
\hline 25 & $\mathrm{~L}+\mathrm{H}^{*} \mathrm{~L} ! \mathrm{H}-$ \\
\hline 12 & $\mathrm{~L}+\mathrm{H}^{*} \mathrm{LH}-$ \\
\hline 52 & $\mathrm{~L}+\mathrm{H}^{*}=-$ \\
\hline 22 & $\mathrm{~L}+! \mathrm{H}^{*}=-$ \\
\hline 9 & $\mathrm{H}=-$ \\
\hline 11 & $! \mathrm{H}^{*}=-$ \\
\hline 10 & $\mathrm{~L}+\mathrm{H}^{*} \mathrm{~L}-$ \\
\hline 9 & $\mathrm{~L}+! \mathrm{H}^{*} \mathrm{~L}-$ \\
\hline 10 & $! \mathrm{H} \mathrm{L}^{-}$ \\
\hline & \\
\hline
\end{tabular}

corpus of read sentences of Peninsular Spanish were analyzed and the statistical treatment showed an association of each tone level to a different meaning: L\% (declarative), !H- (unfinished enumeration), H- (calling contour) and $\mathrm{HH} \%$ (reiterative question). ${ }^{4}$ With respect to their pragmatic interpretation, both $\mathrm{H}$ - and $! \mathrm{H}$ - encode the instruction to understand the propositional content of their ips as part of a larger structure. As a rule, they signal continuity, open-endedness, or non-finality (House, 2006).

Figure 14 exemplifies the occurrence of a mid tone between the ips en esta edición (in this edition) and del Máxima Arte (of Arts Maximal), which clearly contrasts with the continuation rise that closes the adjunct.

\subsubsection{Fall-rise pattern}

Interestingly, the fall-rise pattern was already observed in the pioneering study of Navarro Tomás on Spanish intonation (1944), but he treated it as a marginal non-phonological category. The corpus analysed, however, presents clear instances of such a movement. In line with Estebas-Vilaplana and Prieto (2010) and Hualde and Prieto (2015), we consider it a tonal category (LH-) that can be phonetically realized as a low-to-high pitch movement (LH-) or a low-to-mid pitch movement (L!H-), that is, this bitonal boundary tone can present, after the low tone, a rise to the upper or the mid limit of the speaker tonal range.

\footnotetext{
4 The hard continuation rise ( $\mathrm{HH} \%$ or $i \mathrm{H} \%$ in the notation of EstebasVilaplana and Prieto, 2010, and Hualde and Prieto, 2015, respectively) does not have any occurrence in the Glissando news reading. It indicates a marked rise to the upper limit of the speaker tonal range and it usually represents surprise or echo in exclamatory and interrogative sentences. Then, its absence is explained by the characteristics of the news corpus, constituted by declaratives sentences.
} 
Figure 13: Illustration of a continuation rise in two independent fragments of the corpus: como alubias, garbanzos y judias ('such as pinto beans, chickpeas, and green beans'); se reúnen en Amsterdam ('they meet in Amsterdam').

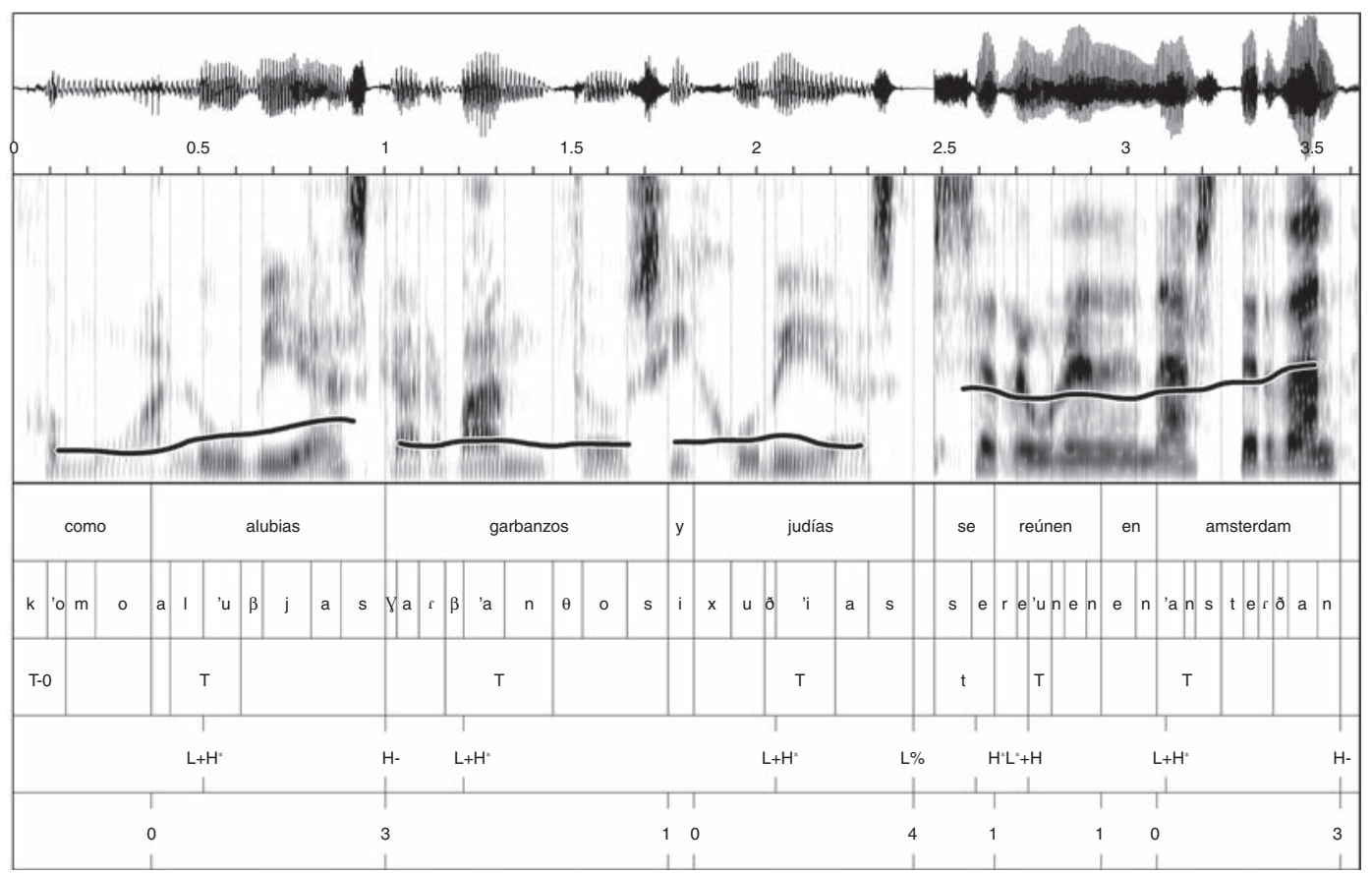

Figure 14: Illustration of !H-. It depicts the intonational characteristics of en esta edición del Máxima Arte ('in this edition of Arts Maximal').

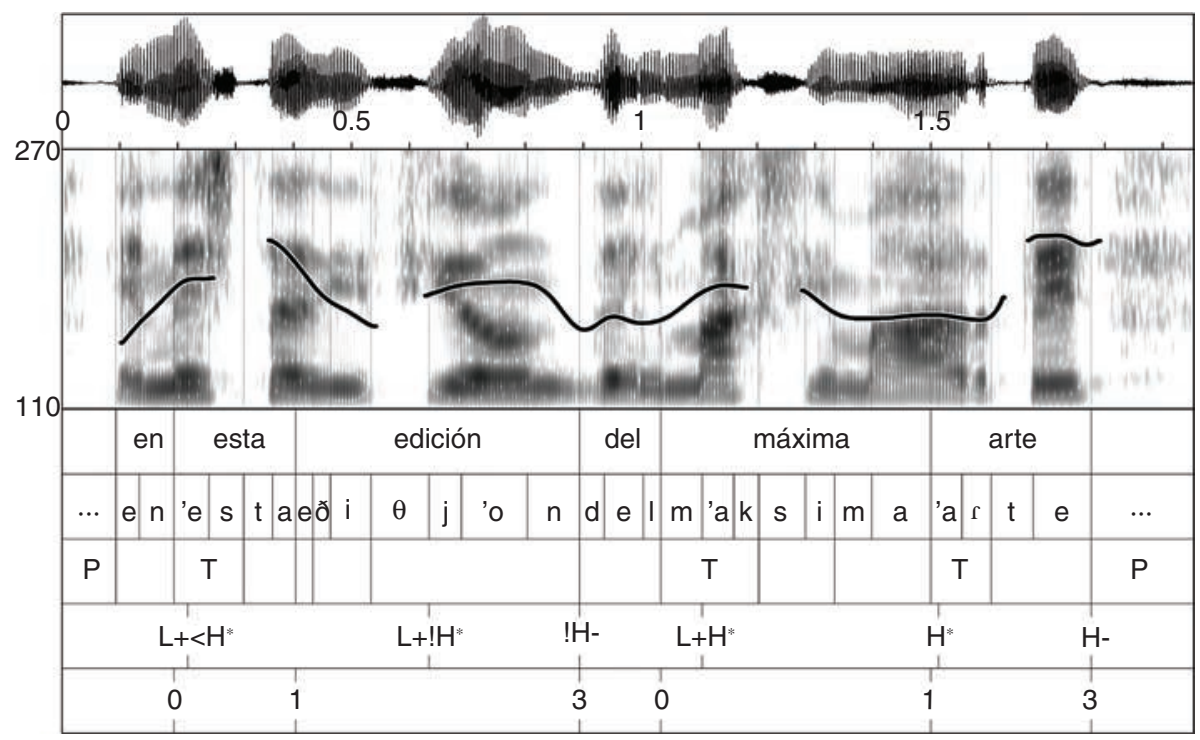

The examples in Figure 15 illustrate these two phonetic realizations of the boundary tone LH-: firstly, the rise reaches a similar level compared with the high nuclear pitch accent (LH- in 'asequibles'); secondly, the boundary tone goes from a high nuclear pitch accent to a low-mid (L!H- in 'Azcárate').

\subsubsection{Sustained pitch}

The sustained pitch serves the purposes of a preamble to further information. It is tonally manifested as maintaining the level of the last tone in the nuclear pitch accent, i.e., it is underspecified for pitch height and what 
Figure 15: Illustration of the fall-rise pattern in independent fragments of the corpus: Azcárate (proper noun) and con productos asequibles ('with affordable products').

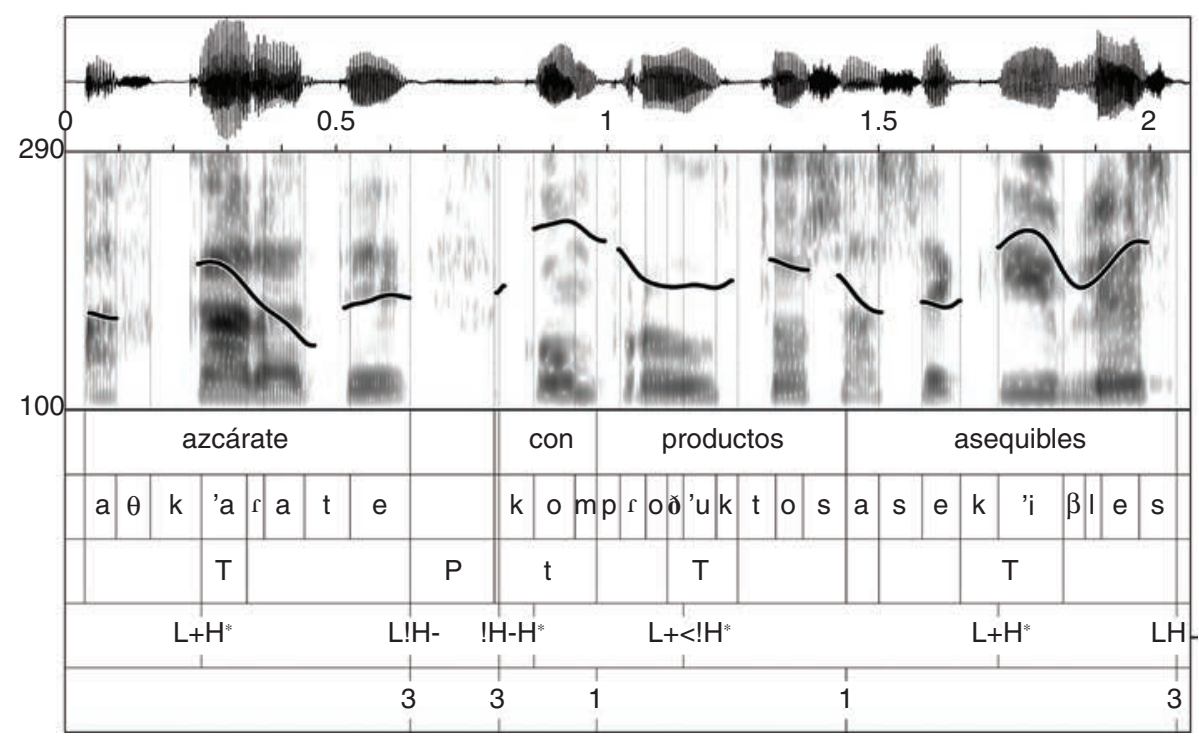

Figure 16: Example of tonal maintenance expressed by a sustained boundary tone after $\mathrm{L}+$ ! $\mathrm{H}^{*}$ and $\mathrm{L}+\mathrm{H}^{*}$ in the prepositional phrase de su libro Otoño y otras luces ('from his book Fall and other lights').

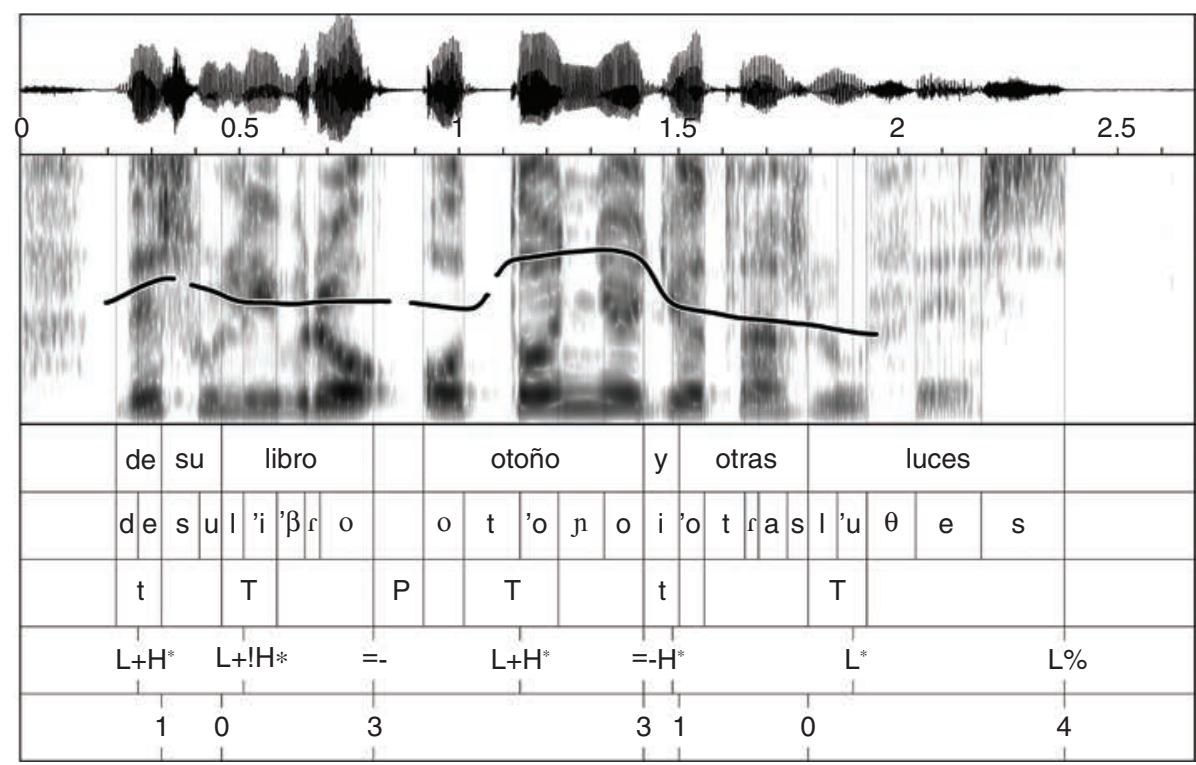

determines its scaling value is the last tonal target in the nuclear pitch accent. Consequently, the sustained pitch can adopt the pitch values of $\mathrm{H}$, ! H, or $\mathrm{L}{ }^{5}$

Figure 16 helps to better understand the tonal preservation expressed by this category, since it appears associated to a mid and also to a high nuclear tone. If the last pitch accent is $\mathrm{L}+! \mathrm{H}^{*}$, the sustained pitch maintains the

5 A detailed phonetic analysis of the sustained pitch is offered in Estebas-Vilaplana et al. (2015), where instances of this tone preceded by a low pitch accent $\left(\mathrm{L}^{*}\right)$ were attested in the dialogue subcorpus of Glissando. final mid pitch target, as in libro 'book', while if the last pitch accent is $\mathrm{L}+\mathrm{H}^{*}$, the sustained pitch remains in a high level (otoño 'fall'). In all cases in the analyzed corpus, this tone correlates with an intermediate phrasing (BI3).

\subsection{Use of rising-falling tunes to signal ends}

According to studies on Spanish prosody, statements with a broad focus intonation typically show a $\mathrm{L}+<\mathrm{H}^{*}$ pitch accent in prenuclear position, indicating that the rising contour is realized within the accented syllable and the $f_{0}$ peak is produced on the postaccentual syllable. 
Figure 17: Example of a rising-falling tune that takes place at the end of an utterance, at the end of a news item. It depicts the intonational characteristics of y a la crisis humanitaria que lo azota ('and the humanitarian crisis that scourges it').

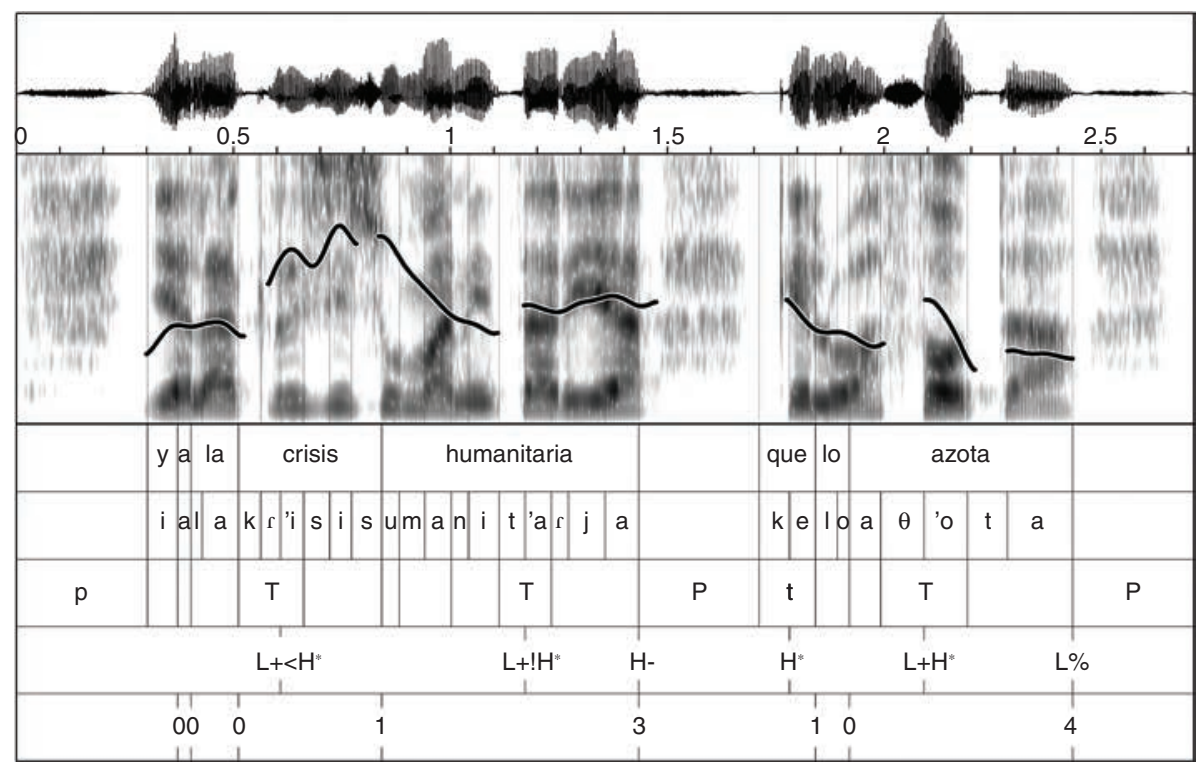

Table 6: Number of cases of tonal contours associated with an intonational phrase (N-BI4). The pitch configurations are sorted by the type of pitch accent.

\begin{tabular}{|l|l|}
\hline $\begin{array}{l}\text { Number of cases } \\
\text { associated with a BI4 }\end{array}$ & Tonal contours \\
\hline 58 & $\mathrm{~L}+\mathrm{H}^{*} \mathrm{~L} \%$ \\
\hline 19 & $\mathrm{~L}+! \mathrm{H}^{*} \mathrm{~L} \%$ \\
\hline 16 & $\mathrm{~L}+{ }_{\mathrm{H}}^{*} \mathrm{~L} \%$ \\
\hline 19 & $! \mathrm{H} * \mathrm{~L} \%$ \\
\hline 14 & $\mathrm{H}^{*} \mathrm{~L} \%$ \\
\hline 72 & $\mathrm{~L} * \mathrm{~L} \%$ \\
\hline
\end{tabular}

A progressively falling contour starts after the final prenuclear syllable and lasts until the end of the sentence. Given the low $f_{0}$ attained during the last accented syllable, this final movement is described by means of a $\mathrm{L}^{*}$ pitch accent followed by a L\% boundary tone (EstebasVilaplana \& Prieto, 2010; Sosa, 1999).

What is relevant in the corpus of news is that, although $\mathrm{L} * \mathrm{~L} \%$ is the dominant nuclear contour combined with a major break (BI4), as shown in Table 6, there are other types of nuclear configurations, unexpected in an unmarked reading style. Broadcasters tend to selectively focus many parts of the stretch of speech. A good illustration of this trend is displayed in Figure 17, where a rising-falling tune occurs at the end of the final utterance of an item of news: $y$ a la crisis humanitaria que lo azota ('and the humanitarian crisis that scourges it'). The use of final rising-falling (or circumflex) contours is a common strategy of professionals when reading news, which has been described in previous studies (de-laMota \& Rodero, 2011).

\section{CONCLUSIONS}

We have analysed, in a corpus of news stories read by professionals, the potential landing sites for tones, as there are unstressed syllables that turn out to exhibit tonal prominence, and vice versa, lexically stressed syllables that lack such prominence; we have described the degree of cohesion holding between the constituents by means of the occurrence of a pause or an initial tonal rise; finally, we have offered a description of the pitch movements that convey non-final or final interpretations in read speech.

Stress modifications can stylistically characterise the speech of news readings by means of the repeated placement of prominence peaks in unstressed syllables. The description shows that $13 \%$ of pitch-accented syllables occurs on lexically unstressed syllables, which compared with what is known for neutral speech, where intonation patterns exhibit covariation between stress and accent, is a significant property. This is clear with polysyllabic words and functional monosyllabic words: as for the first, the accumulation of unstressed syllables is blocked by the occurrence of a secondary stress; as for the second, the formation of clitic groups is not as prevalent as in an unmarked style of reading. A trend towards a trochaic rhythmic pattern irrespective of the lexical structure is observed, but when considering word boundaries, the effect of the initial position arises as the main factor that explains the upgrading of unstressed syllables to accented ones in the news corpus. 
The various modifications in the stress patterns are strengthened by the phrasing and melodic contours. Firstly, phrasing decisions in a news reading style are governed by the type of information that comes after the pause with the location of unexpected pauses and a strong tendency towards a free combination with tonal and prosodic labels: not only can any intonation label be associated with either BI3 or BI4, but also silences can follow $\mathrm{BI} 3$ or BI4.

Secondly, the radio news style's global objective of capturing and maintaining the listener's attention is conveyed by the tonal representation by means of several strategies: prosodic marking of initial edges; choice of pitch accents whose $f_{0}$ peak is within the stressed syllable; use of prosodically marked pitch configurations either in intermediate or final positions. Related to this, it has been attested that the rule according to which only falling nuclear contours express that the content of the sequence has been completed is not so straightforward. The trend to mark prominences along the utterances causes a variety of nuclear configurations signalling either intermediate or final positions.

All the described prosodic and tonal strategies contribute to obtain an emphatic style in the news reading. These findings are in line with those studies that defend that radio news is one of the most characteristic speech styles in contrast to non-professional speech, and that it is representative of a prosodically marked genre (de-laMota \& Rodero, 2011; Escudero, González, Gutiérrez, \& Rodero, 2017; Rodero Antón, 2013) in which a typical chanting style is superimposed to the content of the text.

The descriptive analyses provided here are intended to supply a baseline comparison for future work in read speech by nonprofessional speakers and unread speech.

\section{ACKNOWLEDGEMENTS}

The Glissando corpus was developed thanks to the research project Glissando: A corpus for multidisciplinary prosodic studies in Spanish and Catalan (FFI2008-04982-C03-02/FILO). The research described in this article was partially supported by the projects Modelling prosodic phenomena in Spanish and Catalan using the GLISSANDO corpus (FFI2011-29559-C02-02) and (FFI2011-29440-C03-03).

\section{REFERENCES}

Albelda Marco, M. (2005). Sistemas de transcripción de los corpus orales del español. In M. L. Carrió Pastor (Ed.), Perspectivas interdisciplinares de la lingüística aplicada, Vol. 2, 381-388.

Alcoba, S., \& Murillo, J. (1998). Intonation in Spanish. In D. Hirst \& A. Di Cristo (Eds.), Intonation Systems. A Survey of Twenty Languages (pp. 152-166). Cambridge: Cambridge University Press.

Arvaniti, A. (1994). Acoustic features of Greek rhythmic structure. Journal of Phonetics, 22, 239-268.

Beckman, M. E., \& Ayers, G. (1997). Guidelines for ToBI labelling. The $O S U$ Research Foundation, v. 3.

Beckman, M. E., Díaz-Campos, M., McGory, J. T., \& Morgan, T. A. (2002). Intonation across Spanish, in the Tones and
Break Indices framework. Probus, 14(1), 9-36. https://doi. org/10.1515/prbs. 2002.008

Beckman, M. E., Hirschberg, J., \& Shattuck-Hufnagel, S. (2005). The original ToBI system and the evolution of the ToBI framework. In S.-A. Jun (Ed.), Prosodic phonology: The phonology of intonation and phrasing (pp. 9-54). https://doi. org/10.1093/acprof:oso/9780199249633.003.0002

Bolinger, D. (1986). Intonation and its parts: Melody in spoken English. Stanford University Press.

Botinis, A., Granstrom, B., \& Mobius, B. (2001). Developments and paradigms in intonation research. Speech Communication, 33(4), 263-296. https://doi.org/10.1016/ S0167-6393(00)00060-1

Campione, E., \& Veronis, J. (1998). Multext: A multilingual prosodic database. Proceedings of ICSLP 98, Vol. 7 (pp. 3163-3166)

Canellada, M. J., \& Madsen, J. K. (1987). Pronunciación del español: Lengua hablada y literaria. Madrid: Castalia.

Cole, J. (2015). Prosody in context: A review. Language, Cognition, and Neuroscience, 30(1-2), 1-31. https://doi.org $/ 10.1080 / 23273798.2014 .963130$

Cresti, E., \& Moneglia, M. (2005). C-ORAL-ROM. Integrated reference corpora for spoken romance languages. John Benjamins Studies in Corpus Linguistics, 15. https://doi. org/10.1075/scl.15

de-la-Mota, C., \& Rodero, E. (2011). La entonación en la información radiofónica. In A. Hidalgo Navarro, Y. Congosto Martín \& M. Quilis Merín (Eds.), El estudio de la prosodia en España en el siglo XXI: Perspectivas y ámbitos (pp. 159-176). Facultat de Filologia, Traducció i Comunicació, Universitat de València.

Escudero, D., González, C., Gutiérrez, Y., \& Rodero, E. (2017). Identifying characteristic prosodic patterns through the analysis of the information of Sp_ToBI label sequences. Computer Speech \& Language, 45, 39-57. https://doi.org/10.1016/j.csl.2017.02.011

Escudero-Mancebo, D., Bonafonte, A., Aguilar, L., \& Garrido, J. M. (2009). On the definition of a prosodically balanced corpus: Combining greedy algorithms with expert guided manipulation. Procesamiento del Lenguaje Natural, 43, 93-101.

Estebas Vilaplana, E. (2009). Cuatro niveles de altura tonal en la frontera de frase en español peninsular. Onomázein, 20, 11-32.

Estebas-Vilaplana, E., Gutiérrez, Y. M., Vizcaíno, F., \& Cabrera, M. (2015) Boundary tones in Spanish declaratives: Modelling sustained pitch. In The Scottish Consortium for ICPhS 2015 (Ed.), Proceedings of the 18th International Congress of Phonetic Sciences. Glasgow, UK: The University of Glasgow, paper number 196 , 1-4. Retrieved from https://www.internationalphoneticassociation.org/icphs-proceedings/ICPhS2015/Papers/ ICPHS0196.pdf

Estebas-Vilaplana, E., \& Prieto, P. (2010). Castilian Spanish intonation. In P. Prieto \& P. Roseano (Eds.), Transcription of intonation of the Spanish language (pp. 17-48). Munich: LINCOM Europa.

Face, T. L. (2008). The Intonation of Castilian Spanish declaratives and absolute interrogatives. Muenchen: LINCOM Europa.

Face, T., \& Prieto, P. (2007). Rising accents in Castilian Spanish: A revision of Sp_ToBI. Journal of Portuguese Linguistics, 5-6, 117-146. https://doi.org/10.5334/jpl.147

Farnetani, E., \& Kori, E. (1983). Interaction of syntactic structure and rhythmical constraints on the realization of word prosody. Quaderni del Centro di Studio per le Ricerche di Fonetica (Padova) , 2, 288-318.

Fernández Planas, A. M. (2005). Aspectos generales acerca del proyecto internacional "AMPER" en España. Estudios de Fonética Experimental, 14, 13-27.

Frota, S., D'Imperio, M., Elordieta, G., Prieto, P., \& Vigário, M. (2007). The phonetics and phonology of intonational phrasing in Romance. In P. Prieto, J. Mascaró, \& M.-J. Solé (Eds.), Segmental and prosodic issues in Romance phonology (pp. 131-153). Amsterdam: John Benjamins. https:// doi.org/10.1075/cilt.282.10fro 
Frota, S., \& Prieto, P. (Eds.) (2015). Intonation in Romance. Oxford: Oxford University Press. https://doi.org/10.1093/ acprof:oso/9780199685332.003.0011

Garrido, J. M., Escudero, D., Aguilar, L., Cardeñoso, V., Rodero, E., de-La-Mota, C., . . \& \& Bonafonte, A. (2013). Glissando: A corpus for multidisciplinary prosodic studies in Spanish and Catalan. Language Resources and Evaluation, 47(4), 945-971.

Gutiérrez González, Y. M. \& Aguilar, L. (2015). Nuevos datos empíricos sobre la entonación del español a partir del corpus de noticias Glissando. Estudios de Fonética Experimental, 24, 35-82.

House, J. (2006). Constructing a context with intonation. Journal of Pragmatics, 38(10), 1542-1558. https://doi. org/10.1016/j.pragma.2005.07.005

Hualde, J. I. (2002). Intonation in Spanish and the other IberoRomance languages: Overview and status quaestionis. In C. R. Wiltshire \& J. Camps (Eds.), Romance phonology and variation: Selected papers from the 30th Linguistic Symposium on Romance Languages, Gainesville, Florida, February 2000 (pp. 101-116). Amsterdam: John Benjamins. https://doi.org/10.1075/cilt.217.10hua

Hualde, J. I. (2007). Stress removal and stress addition in Spanish. Journal of Portuguese Linguistics, 6(1), 59-89. https://doi.org/10.5334/jpl.145

Hualde, J. I., \& Prieto, P. (2015). Intonational variation in Spanish: European and American varieties. In S. Frota \& P. Prieto (Eds.), Intonation in Romance (pp. 350-391). Oxford: Oxford University Press. https://doi.org/10.1093/ acprof:oso/9780199685332.003.0010

Ladd, D. R. (2008) (2nd ed.). Intonational phonology. Cambridge: Cambridge University Press. https://doi.org/10.1017/ CBO9780511808814

Liberman, M., \& Prince, A. (1977). On stress and linguistic rhythm. Linguistic Inquiry, 8(2), 249-336.

Marín, R., Aguilar, L., \& Casacuberta, D. (2002). Placing pauses in read spoken Spanish: A model and an algorithm. Language Design, 4, 49-66.

Navarro Tomás, T. (1925). Palabras sin acento. Revista de Filología Española, 12(4), 335-375.

Navarro Tomás, T. (1944). Manual de entonación española. New York: Hispanic Institute in the United States.

Nespor, M., \& Vogel, I. (1994 [1986]) (Spanish trans.). Madrid: Visor.

Ortega-Llebaria, M., \& Prieto, P. (2007). Disentangling stress from accent in Spanish: Production patterns of the stress contrast in deaccented syllables. In P. Prieto, J. Mascaró, \& M.-J. Solé (Eds.), Segmental and prosodic issues in Romance phonology (pp. 155-197). Amsterdam: John Benjamins. https://doi.org/10.1075/cilt.282.11ort

Ortega-Llebaria, M., \& Prieto, P. (2011). Acoustic correlates of stress in Central Catalan and Castilian Spanish. Language and Speech, 54(1), 73-97. https://doi. org/10.1177/0023830910388014

Pamies Bertrán, A., Fernández Planas, A. M., Martínez Celdrán, E., Ortega Escandell, A., \& Amorós Céspedes, M. C. (2002).
Umbrales tonales en español peninsular. In J. Díaz García (Ed.), Actas del II Congreso de Fonética Experimental (pp. 272-278). Sevilla: Universidad de Sevilla.

Penny, R. (2000). Variation and change in Spanish. Cambridge: Cambridge University Press. https://doi.org/10.1017/ CBO9781139164566

Pierrehumbert, J., and Hirschberg, J. (1990). The meaning of intonational contours in the interpretation of discourse. In P. R. Cohen, J. Morgan, \& M. E. Pollack (Eds.): Intentions in communication (pp. 271-312). Cambridge, MA: MIT Press.

Prieto, P. (2005). Stability effects in tonal clash contexts in Catalan. Journal of Phonetics, 33(2), 215-242. https://doi. org/10.1016/j.wocn.2004.07.001

Prieto, P., \& Ortega-Llebaria, M. (2006). Stress and accent in Catalan and Spanish: Patterns of duration, vowel quality, overall intensity, and spectral balance. In R. Hoffmann \& H. Mixdorf (Eds.), Proceedings of Speech Prosody 2006, Dresden, Germany (pp. 337-340).

Prieto, P. \& Roseano, P. (Dirs.) (2009-2013). Atlas interactivo de la entonación del español. http://prosodia.upf.edu/ atlasentonacion/

Prieto, P., \& Roseano, P. (Eds.) (2010). Transcription of intonation of the Spanish language. Munich: LINCOM Europa.

Quilis, A. (1983). Frecuencia de los esquemas acentuales en español. In Estudios ofrecidos a Emilio Alarcos Llorach, Vol. 5 (pp. 113-126)

Quilis, A. (1993). Tratado de fonología y fonética españolas. Madrid: Gredos.

Rietveld, A. C. M., \& Gussenhoven, C. (1985). On the relation between pitch excursion size and prominence. Journal of Phonetics, 13, 299-308.

Rodero Antón, E. (2013). Peculiar styles when narrating the news: The intonation of radio news bulletins. Estudios sobre el Mensaje Periodístico, 19(1), 519-532. https://doi. org/10.5209/rev ESMP.2013.v19.n1.42536

Sosa, J. M. (1999). La entonación del español: Su estructura fónica, variabilidad y dialectología. Barcelona: Cátedra.

Torreira, F., Simonet, M., \& Hualde, J. I. (2014). Quasineutralization of stress contrasts in Spanish. In N. Campbell, D. Gibbon, \& D. Hirst (Eds.), Proceedings of the 7th International Conference on Speech Prosody (Speech Prosody 7) (pp. 197-201).

Wagner, P., Origlia, A., Avesani, C., Christodoulides, G., Cutugno, F., D'Imperio, M., . . . \& Vainio, M. (2015). Different parts of the same elephant: A roadmap to disentangle and connect different perspectives on prosodic prominence. In The Scottish Consortium for ICPhS 2015 (Ed.), Proceedings of the 18th International Congress of Phonetic Sciences. Glasgow, UK: The University of Glasgow, paper number 202, 1-5. Retrieved from https:// www.internationalphoneticassociation.org/icphs-proceedings/ICPhS2015/Papers/ICPHS0202.pdf

Xu, Y., \& Xu, C. X. (2005). Phonetic realization of focus in English declarative intonation. Journal of Phonetics, 33(2), 159-197. https://doi.org/10.1016/j.wocn.2004.11.001 